\title{
Transcriptomic and physiological responses to fishmeal substitution with plant proteins in formulated feed in farmed Atlantic salmon (Salmo salar)
}

Luca Tacchi ${ }^{1}$, Christopher J Secombes ${ }^{1}$, Ralph Bickerdike², Michael A Adler ${ }^{2}$, Claudia Venegas ${ }^{3}$, Harald Takle ${ }^{3,4}$ and Samuel AM Martin ${ }^{1 *}$

\begin{abstract}
Background: Aquaculture of piscivorous fish is in continual expansion resulting in a global requirement to reduce the dependence on wild caught fish for generation of fishmeal and fish oil. Plant proteins represent a suitable protein alternative to fish meal and are increasingly being used in fish feed. In this study, we examined the transcriptional response of Atlantic salmon (Salmo salar) to a high marine protein (MP) or low fishmeal, higher plant protein replacement diet (PP), formulated to the same nutritional specification within previously determined acceptable maximum levels of individual plant feed materials.

Results: After 77 days of feeding the fish in both groups doubled in weight, however neither growth performance, feed efficiency, condition factor nor organ indices were significantly different. Assessment of histopathological changes in the heart, intestine or liver did not reveal any negative effects of the PP diet. Transcriptomic analysis was performed in mid intestine, liver and skeletal muscle, using an Atlantic salmon oligonucleotide microarray (Salar_2, Agilent $4 \times 44 K$ ). The dietary comparison revealed large alteration in gene expression in all the tissues studied between fish on the two diets. Gene ontology analysis showed, in the mid intestine of fish fed PP, higher expression of genes involved in enteritis, protein and energy metabolism, mitochondrial activity/kinases and transport, and a lower expression of genes involved in cell proliferation and apoptosis compared to fish fed MP. The liver of fish fed PP showed a lower expression of immune response genes but a higher expression of cell proliferation and apoptosis processes that may lead to cell reorganization in this tissue. The skeletal muscle of fish fed PP vs MP was characterized by a suppression of processes including immune response, energy and protein metabolism, cell proliferation and apoptosis which may reflect a more energy efficient tissue.
\end{abstract}

Conclusions: The PP diet resulted in significant effects on transcription in all the 3 tissues studied. Despite of these alterations, we demonstrated that high level of plant derived proteins in a salmon diet allowed fish to grow with equal efficiency as those on a high marine protein diet, and with no difference in biometric quality parameters.

\footnotetext{
* Correspondence: sam.martin@abdn.ac.uk

${ }^{1}$ Institute of Biological and Environmental Sciences, University of Aberdeen,

Tillydrone Avenue, Aberdeen AB24 2TZ, UK

Full list of author information is available at the end of the article
} 


\section{Background}

Aquaculture production has been the fastest growing animal food-producing sector globally for over half a century, with production growing at an average rate of $8.1 \%$ per year since 1961 [1], representing almost $50 \%$ of human consumed fish [1,2]. Additionally, the capture from wild fisheries has plateaued with approximately three quarters of wild fisheries fished to capacity, overfished or recovering [3]. Atlantic salmon (Salmo salar) production alone now reaches over 1.5 million tonnes per year [4]. Total production in 2008 is estimated at 1.4 million tonnes, representing a 6\% increase on 2007 [5]. The positive growth trend of the industry is expected to continue, reflecting the rising demand for healthy human food products high in protein and marine oils.

Piscivorous fish, which include salmonids, require high protein diets and until recently this was almost exclusively derived from wild caught non food fish such as anchovies and sardines. It has become apparent that with increasing fish meal demand due to the expanding aquaculture industry the proportion of protein in diets cannot be sustained by use of fish meal alone. During 2003, 20\% of total fish meal usage for aquaculture feed production was utilized by the salmon industry [6], but continued development of diets has reduced the inclusion of fish meal in salmon diets from $500 \mathrm{~g} \mathrm{~kg}^{-1}$ to $350 \mathrm{~g}$ $\mathrm{kg}^{-1}$ by replacement with alternative protein sources [7]. Plant proteins currently represent the only economic and sustainable protein alternative to fish meal and are increasingly being used in commercial fish feed, with the most common being soybean meal (SBM) or soybean protein concentrate (SPC) which have a high protein content and contain the majority of essential amino acids required by salmonids. All plants contain a number of anti nutritional factors (ANFs) as part of their inherent defence mechanisms, effected by lectins, saponins, phytic acid and proteinase inhibitors amongst others [8]. In early attempts to use plant proteins in fish diets ANFs were often co purified with the proteins, leading to metabolic dysfunction in fish liver [9], inflammation in the intestine $[10,11]$, reduced protein deposition [12], and an impaired immune response [13]. Currently used plant replacement diets use a combination of different plant proteins, with SPC often the major component [14]. Processing of soy protein to SPC with alcohol-extraction removes the majority of ANFs facilitating use of these products in fish feeds at a high inclusion level without causing enteritis or other gross morphological changes [15]. Replacement of up to $50 \%$ of the fish meal with a mixture of plant proteins is possible in rainbow trout without affecting fish growth, and even complete replacement of fish meal with SPC has been reported [16,17]. Other successful plant proteins used regularly in aquaculture include wheat gluten at up to $40 \%$ of fish meal replacement in feed for salmon and trout (Hardy 1996), corn gluten and sunflower meal at up to $30 \%$ replacement, which show no adverse effects on salmonid growth performance [18-20]. Extensive studies investigating responses of Atlantic salmon to such diets indicate that a replacement of fish meal close to $100 \%$ can be used without negative effects on salmon growth providing the proteins are highly purified and the amino acid profile is well balanced [21]. High levels of pea protein concentrate do still cause enteropathy in salmon though [22].

In this paper we report a whole transcriptome based study on post-smolt Atlantic salmon fed on a low marine protein diet, where marine protein fish meal was partially replaced with a combination of plant derived proteins, compared to fish fed a diet high in fish meal. The high plant protein (PP) diet contained a balanced combination of soy protein concentrate, corn gluten and wheat gluten, and was supplemented with lysine and methionine to ensure the requirement for essential amino acids was met. The fish were fed for 77 days following which growth, feed efficiency and quality biometric parameters were measured and tissues were collected for histopathological changes and gene transcription analysis. The transcriptional response was examined using an Atlantic salmon"salar_2" microarray platform (Agilent) [23], enriched for genes involved in protein metabolism, lipid metabolism and immune function.

\section{Results}

\section{Feeding trial}

During the 77 day feeding trial fish were fed either a high marine protein (MP) diet or a plant protein replacement (PP) diet (Table 1), and both groups doubled in weight over this period. No significant differences were seen between the groups in growth performance, feeding efficiency, condition factor or organ indexes (Table 2). There were also no significant mortalities in any of the tanks.

\section{Histology}

A number of histological changes were found, however different types of anomalies were observed in tissues of individuals from both treatment groups and such changes were observed in low frequency indicating that the fish were in a good condition (Table 3). There was no significant dietary effect for any histological change except the frequency of perivascular and peri-biliar duct infiltrations in the liver, where $21 \%$ of fish fed the MP diet exhibited this change compared to $3.8 \%$ of fish fed the PP diet (Table 3). A number of fish from both diets showed a mild fatty change in the liver, but this was not restricted to a particular dietary group (Table 3). Equally, some anomalies in heart were observed at a low level in 
Table 1 Dietary formulations

\begin{tabular}{lcc}
\hline & PP & MP \\
\hline Raw Materials (\% of inclusion) & 26.0 & 51.0 \\
\hline Fish meal (\%) & 19.2 & 17.3 \\
\hline Fish oil (\%) & 6.3 & 11.9 \\
\hline Wheat (\%) & 10.0 & 3.0 \\
\hline Maize gluten (\%) & 15.0 & 10.0 \\
\hline Sunflower meal (\%) & 3.0 & 3.0 \\
\hline Rapeseed meal (\%) & 1.3 & \\
\hline Wheat gluten (\%) & 18.0 & 3.0 \\
\hline Soy protein concentrate(\%) & 0.4 & 0.4 \\
\hline Premix (\%) & 0.5 & 0.3 \\
\hline Monocalcium phosphate (\%) & 0.3 & \\
\hline Lysine (\%) & 0.1 & \\
\hline Methionine(\%) & & \\
\hline Proximate Analysis (\% in feed) & 44.8 & 44.3 \\
\hline Protein (\%) & 23.5 & 24 \\
\hline Oil(\%) & 6.8 & 8.9 \\
\hline Ash(\%) & 7.7 & 8.5 \\
\hline Moisture(\%) & $39 \%$ & $78 \%$ \\
\hline Marine protein (as \% of total Crude Protein) & & \\
\hline Detary formulton & & \\
\hline
\end{tabular}

Dietary formulation of high marine protein diet (MP) and plant protein diet (PP). Values represent percentage inclusion or content. Marine content calculated for total protein. The Fish oil is a commercial Chilean fish oil.

both dietary treatments. For the intestine, no changes were observed in pyloric caeca or mid intestine, whereas for the distal intestine an inflammatory infiltration in the submucosa and lamina propria was observed but at a low level in both diets, with no significant difference in occurrence between dietary groups (Table 3).

\section{Transcriptomic responses}

Fish fed the PP diet showed changes in transcriptome in all 3 tissues examined compared to fish fed the marine

Table 2 Growth performance and somatic indexes

\begin{tabular}{lccccc}
\hline & PP & & MP & \\
\cline { 2 - 3 } & Mean & +/- SD & & Mean & +/- SD \\
\hline Initial Weight (g) & 110.6 & 0.8 & 110.8 & 0.4 \\
\hline Final Weight (g) & 231.4 & 1.9 & 237.0 & 3.2 \\
\hline SGR (\%) & 1.09 & 0.02 & 1.12 & 0.02 \\
\hline FCR & 0.87 & 0.01 & 0.90 & 0.03 \\
\hline SFR (\%) & 0.95 & 0.02 & 1.00 & 0.04 \\
\hline Condition factor & 1.08 & 0.00 & 1.06 & 0.03 \\
\hline CSI & 0.08 & 0.00 & 0.08 & 0.01 \\
\hline HSI & 1.09 & 0.07 & 1.06 & 0.02 \\
\hline ISI & 2.32 & 0.20 & 2.40 & 0.20 \\
\hline
\end{tabular}

Growth performance and somatic indexes. SGR represents the specific growth rate of fish, FCR is the feed conversion ratio, SFR is the specific feeding rate, CSI is the cardiac somatic indice, HSI is the hepatic somatic indice and ISI is the intestinal somatic indice. protein rich diet MP. In total 8,151 oligo features were found to be expressed at different levels as a result of the dietary manipulation. For subsequent analysis only significant $(p<0.05)$ features with a fold difference of greater than 2 were analysed further (1961 mRNAs). The intestine exhibited the greatest differential gene expression with 1,236 genes significantly different in expression level between fish fed the PP diet and MP diet. Of these 615 genes were higher in expression and 621 lower in PP fed fish. In skeletal muscle 505 genes had an expression higher than two fold with 132 higher in PP fed fish and 373 lower and in liver 220 genes were found modified with 161 higher and 59 genes lower in PP fed fish vs MP fed fish (Table 4).

There were no genes expressed at different levels in common between all the tissues examined indicating there was not a systematic response to the diets. However there was a co regulation of features between the mid intestine and skeletal muscle with 9 genes higher in both tissues of PP fed fish vs MP fed fish and 10 lower in both. Similarly in the liver and intestine 6 genes were found to be significantly different in common, with 5 genes higher in expression and 1 gene lower in the PP fed fish. To further investigate the biological significance of the differently expressed gene sets we used gene ontology analysis to help identify biological processes that were significantly different in tissues following the feeding trial.

Annotation of the microarray allowed $77 \%$ of the features to be allocated to a functional protein and $55 \%$ of these proteins were assigned a gene ontology (GO) identifier. This allowed statistical analysis for enrichment for GO biological processes to help interpret the changes in the transcriptome following the feeding trial (Figure 1) to gain a holistic view of which biological processes were significantly modified following feeding the PP diet.

\section{Genes expressed at different levels in mid intestine}

The intestine is the major tissue to come into direct contact with any feed components and for this reason may be very sensitive to dietary changes. This is shown here by the intestine having the greatest transcriptional response in terms of the number of genes expressed at different levels and the magnitude of different expression of these genes. Several biological processes were significantly different in the PP diet fed fish, related to intestinal functions including immune and stress related processes, protein metabolism, energy and mitochondrial activity, lipid metabolism and transport (Table 4).

\section{Immune and stress response}

Genes encoding proteins related to both innate and acquired immune function were expressed at different 
Table 3 Histopathological observations/changes

\begin{tabular}{|c|c|c|c|c|}
\hline Organ & Changes & PP & MP & $P$-value* \\
\hline \multirow[t]{15}{*}{ Liver } & No significant findings & $39.0 \%$ & $33.3 \%$ & 0.39 \\
\hline & Mild fatty change & $38.1 \%$ & $31.4 \%$ & 0.312 \\
\hline & Mild to moderate fatty change & $8.6 \%$ & $7.6 \%$ & 0.801 \\
\hline & Moderate fatty change & $8.6 \%$ & $8.6 \%$ & n.d. \\
\hline & Moderate to severe fatty change & $0.0 \%$ & $1.9 \%$ & 0.156 \\
\hline & Severe fatty change & $0.0 \%$ & $0.0 \%$ & n.d. \\
\hline & Perivascular infiltration & $2.9 \%$ & $6.7 \%$ & 0.196 \\
\hline & Peri biliar ducts infiltration & $3.8 \%^{\mathrm{a}}$ & $21.0 \%$ & $<0.001$ \\
\hline & Necrotic foci w/infiltration & $1.0 \%$ & $0.0 \%$ & 0.317 \\
\hline & Mild congestion & $0.0 \%$ & $1.0 \%$ & 0.317 \\
\hline & Focal necrosis & $0.0 \%$ & $2.9 \%$ & 0.082 \\
\hline & Mild sinusoidal dilatation & $0.0 \%$ & $1.0 \%$ & 0.317 \\
\hline & Biliar ducts esclerosis & $0.0 \%$ & $2.9 \%$ & 0.082 \\
\hline & Biliar ducts proliferation & $0.0 \%$ & $0.0 \%$ & n.d. \\
\hline & Foci of inflammatory cells & $0.0 \%$ & $1.0 \%$ & 0.317 \\
\hline \multirow[t]{4}{*}{ Heart (ventricle) } & No significant findings & $99.0 \%$ & $98.1 \%$ & 0.562 \\
\hline & Severe infiltration and myodegeneration & $1.0 \%$ & $1.0 \%$ & n.d. \\
\hline & Infiltration, no myodegeneration & $0.0 \%$ & $1.0 \%$ & 0.317 \\
\hline & Presence of melanin granules & $0.0 \%$ & $0.0 \%$ & n.d. \\
\hline Mid-intestine and Pyloric caeca & No significant findings & $100 \%$ & $100 \%$ & n.d. \\
\hline \multirow[t]{2}{*}{ Distal intestine } & No significant findings & $97.1 \%$ & $95.2 \%$ & 0.472 \\
\hline & $\begin{array}{l}\text { Infiltration of submucosa and lamina propria, } \\
\text { widened of lamina propria within folds (simple and complex), } \\
\text { prominent goblet cells/low number of supranuclear vacuoles }\end{array}$ & $2.9 \%$ & $4.8 \%$ & 0.472 \\
\hline
\end{tabular}

Histopathological observations/changes. Values (in percentage) represent occurrence where $n=105$. Significantly different when $\mathrm{P}<0.05$, different superscript letters indicate significant differences within each row-wise comparison.

levels by the dietary treatments. For fish fed PP innate immune parameters were found to be both higher and lower in expression indicating a dynamic response. Modulators of the immune response were higher in PP fed fish, such as MyD88, a key transcription factor associated with induction of an inflammatory response and P105 subunit of an inhibitory protein that sequesters NF- $\kappa \mathrm{B}$ in the cytoplasm. Another transcription factor, interferon regulatory factor (IRF) 1 was also higher, and potentially increased expression of interferon responsive genes including $\mathrm{Mx}$, Vig-2, interferon induced protein 35 and virus induced TRIM protein. Genes encoding cytokine receptors (IL-17R) and regulators of cytokine function including the suppressor of cytokine signalling (SOCS)-7) were also higher. A number of genes related to innate immune responses were also lower, and included IL-17D, MCSFR and chemokines such as CCL3, CXC13 and IL-8 (CXCL8). Other innate immune serum proteins were also lower in expression including serum amyloid A, and a number of lectins. Genes related to proteins in the acquired immune response were mostly higher in expression in fish fed the PP diet compared to the MP diet. For example, T cell receptor chains ( $\alpha$ and $\gamma$ ) and their signalling subunits CD3 epsilon and gamma/delta were higher as were genes involved with antigen presentation such as $\beta 2$ microglobulin and MHC class II). Related to antibody production by $\mathrm{B}$ cells, a B-cell linker protein that regulates B-cell function and development was higher in PP fed fish as was a B cell enhancing factor.

Regarding stress related genes, PP fed fish showed an elevated expression of glutathione-S-transferase and a thioredoxin interacting protein, involved in reducing oxidative stress, while heat shock proteins (HSP) $\beta-7$, $\beta-11,30$ and 70a were all suppressed.

\section{Cell proliferation and apoptosis}

The intestinal transcription of genes encoding proteins related to cell proliferation (tumor necrosis alpha-induced protein 2 , tetraspanins- 14 and -16 and melanoma-derived growth regulatory protein) and the cell cycle (DNA topoisomerase 2-alpha, replication factor $C$ subunit 3, FGFR3 protein, cyclin A1) were found to be higher in PP fed fish; whilst transcription of caspases 3,8 and 14, which are directly involved in apoptosis, were found to be lower in expression relative to fish fed MP. 
Table 4 Genes significantly different in mid intestine of fish fed PP diet

\begin{tabular}{|c|c|c|c|}
\hline Probe name ${ }^{1}$ & $\mathrm{ACC}^{2}$ & $\mathrm{FC} \pm \mathrm{SEM}^{3}$ & Identity $^{4}$ \\
\hline \multicolumn{4}{|c|}{ Immune function and stress related } \\
\hline Ssa\#CK897125 & CK897125 & $7.6 \pm 1.1$ & B-cell linker \\
\hline Ssa\#CL60Contig3 & X70167 & $5.2 \pm 1.2$ & MHC class II antigen beta chain \\
\hline Ssa\#STIR13675 & TC71772 & $5.0 \pm 1.3$ & CD209f \\
\hline Ssa\#NP9934055 & NP9934055 & $4.8 \pm 1.4$ & T cell receptor alpha \\
\hline Ssa\#STIR21272 & TC82967 & $4.3 \pm 1.2$ & Interferon inducible $\mathrm{mx}$ protein \\
\hline Ssa\#S35685629 & S35685629 & $4.3 \pm 1.0$ & TCR-gamma \\
\hline Ssa\#S30239635 & S30239635 & $2.8 \pm 1.2$ & IRF1 \\
\hline Ssa\#STIR10385 & TC67231 & $2.5 \pm 1.1$ & Vig-2 protein \\
\hline Ssa\#STIR15805 & TC74805 & $2.4 \pm 1.0$ & cd3 epsilon \\
\hline Ssa\#STIR05606 & BT056756 & $2.4 \pm 1.1$ & $\beta 2$ microglobulin \\
\hline Ssa\#gi156446662 & EF579742 & $2.0 \pm 1.2$ & MyD88 \\
\hline Ssa\#CL81Contig1 & BT072778 & $2.0 \pm 1.1$ & Virus induced TRIM protein \\
\hline Ssa\#S37438814 & S37438814 & $2.0 \pm 1.0$ & CD3 gamma/delta \\
\hline Ssa\#STIR00071_2 & DW580947 & $2.0 \pm 1.2$ & Interferon induced protein 35 \\
\hline Ssa\#S18833713 & S18833713 & $-7.5 \pm 1.2$ & Serum lectin 2 \\
\hline Ssa\#CK882427 & CK882427 & $-3.2 \pm 1.3$ & Serum amyloid $\mathrm{A}$ \\
\hline Ssa\#S35474845 & S35474845 & $-3.0 \pm 1.1$ & HSP $\beta-7$ \\
\hline Ssa\#S35677496 & S35677496 & $-2.9 \pm 1.1$ & CCR3 \\
\hline Ssa\#S31986130 & S31986130 & $-2.7 \pm 1.2$ & $\begin{array}{l}\text { Macrophage colony stimulating } \\
\text { factor receptor }\end{array}$ \\
\hline Ssa\#S18892409 & S18892409 & $-2.7 \pm 1.1$ & $\lg M$ \\
\hline Ssa\#STIR03818 & NM_001141099 & $-2.4 \pm 1.3$ & $\mathrm{CXC13}$ \\
\hline Ssa\#STIR19205 & TC79827 & $-2.3 \pm 1.1$ & HSP 70a \\
\hline Ssa\#STIR13083 & TC70912 & $-2.3 \pm 1.2$ & SAMHD1 \\
\hline Ssa\#S35663823 & S35663823 & $-2.2 \pm 1.2$ & Complement clq \\
\hline Ssa\#S35583279 & S35583279 & $-2.1 \pm 1.0$ & IL-17D \\
\hline Ssa\#S35517748 & S35517748 & $-2.0 \pm 1.1$ & HSP 30 \\
\hline Ssa\#S35536386 & S35536386 & $-2.0 \pm 1.1$ & HSP $\beta-11$ \\
\hline Omy\#gi31087931 & AY160984 & $-2.0 \pm 1.2$ & IL-8 \\
\hline Ssa\#TC106255 & TC106255 & $-2.0 \pm 1.1$ & Galectin-4 \\
\hline \multicolumn{4}{|c|}{ Cell proliferation and apoptosis } \\
\hline Ssa\#S35582566 & S35582566 & $7.1 \pm 1.2$ & Caspase-14 \\
\hline Ssa\#CL201Ctg1 & NM_001139921 & $2.4 \pm 1.0$ & Caspase-3 \\
\hline Ssa\#S35693335 & S35693335 & $2.2 \pm 1.0$ & Caspase 8 \\
\hline Ssa\#S32005165 & S32005165 & $-9.4 \pm 1.0$ & DNA topoisomerase 2-alpha \\
\hline Omy\#S34421775 & S34421775 & $-6.6 \pm 1.5$ & Replication factor $\mathrm{C}$ subunit 3 \\
\hline Omy\#CA346576 & CA346576 & $-4.5 \pm 1.2$ & Tetraspanin-14 \\
\hline Ssa\#CA038824 & CA038824 & $-3.9 \pm 1.1$ & Fgfr3 protein \\
\hline Omy\#S34313679 & S34313679 & $-3.6 \pm 1.4$ & Cyclin A1 \\
\hline Omy\#S22901990 & S22901990 & $-3.4 \pm 1.0$ & $\begin{array}{l}\text { Chromodomain-helicase-DNA-binding } \\
\text { protein } 7\end{array}$ \\
\hline Ssa\#S47728937 & S47728937 & $-3.1 \pm 1.1$ & Tetraspanin-16 \\
\hline Ssa\#S35496360 & S35496360 & $-2.9 \pm 1.0$ & DNA-repair protein complementing XP-A cells \\
\hline Ssa\#\#35490761_S & S35490761 & $-2.7 \pm 1.1$ & Transcription factor HES-1 \\
\hline Ssa\#STIR38390 & TC108636 & $-2.7 \pm 1.3$ & RNA helicase \\
\hline Ssa\#S35531441 & S35531441 & $-2.4 \pm 1.1$ & $\begin{array}{l}\text { Melanoma-derived growth } \\
\text { regulatory protein }\end{array}$ \\
\hline
\end{tabular}


Table 4 Genes significantly different in mid intestine of fish fed PP diet (Continued)

\begin{tabular}{|c|c|c|c|}
\hline Ssa\#STIR17200 & TC76867 & $-2.4 \pm 1.0$ & Tumor necrosisalpha-induced protein 2 \\
\hline \multicolumn{4}{|c|}{ Protein metabolism } \\
\hline Ssa\#S35499913 & S35499913 & $6.5 \pm 1.0$ & Titin \\
\hline Ssa\#S31974046 & S31974046 & $4.2 \pm 1.1$ & Cathepsin C \\
\hline Ssa\#S30293144 & S30293144 & $3.9 \pm 1.5$ & Proteasome subunit alpha type- 5 \\
\hline Ssa\#STIR05302 & BT046757 & $3.2 \pm 1.1$ & Proteasome subunit beta type- 7 \\
\hline Ssa\#CL233Ctg1 & BT072668 & $3.0 \pm 1.0$ & Cathepsin Z \\
\hline Omy\#S15290109 & S15290109 & $3.0 \pm 1.2$ & Keratin e1 \\
\hline Ssa\#STIR25562 & TC89420 & $3.0 \pm 1.1$ & Troponinskeletal muscle \\
\hline Ssa\#STIR20536 & TC81827 & $2.9 \pm 1.1$ & Cathepsin A \\
\hline Ssa\#STIR24947 & TC88495 & $2.8 \pm 1.2$ & Keratin 18 \\
\hline Ssa\#DY714088 & DY714088 & $2.7 \pm 1.0$ & Ribosomal protein $\mathrm{S6}$ kinase $b$ \\
\hline Ssa\#KSS4531 & KSS4531 & $2.6 \pm 1.1$ & Ubiquitin-conjugating enzyme E2 \\
\hline Ssa\#STIR08978 & TC65424 & $2.2 \pm 1.0$ & $\begin{array}{l}\text { Eukaryotic translation } \\
\text { initiation factor } 4 \mathrm{e}\end{array}$ \\
\hline Ssa\#DY712052 & DY712052 & $2.0 \pm 1.1$ & $\begin{array}{l}\text { Gamma-tubulin complex } \\
\text { component } 4\end{array}$ \\
\hline Ssa\#S30279979 & S30279979 & $2.0 \pm 1.2$ & $\begin{array}{l}\text { Eukaryotic translation initiation } \\
\text { factor } 2 \text { subunit } 1\end{array}$ \\
\hline Ssa\#S30240560 & S30240560 & $2.0 \pm 1.2$ & $\beta$-actin \\
\hline Ssa\#KSS1565 & KSS1565 & $2.0 \pm 1.0$ & Proteasome subunit alpha type- 6 \\
\hline Ssa\#KSSb2668 & KSSb2668 & $2.0 \pm 1.2$ & Tubulin beta- 1 chain \\
\hline Ssa\#STIR39880 & TC110797 & $2.0 \pm 1.1$ & $\begin{array}{l}\text { Proteasome subunit } \\
\text { alpha type-7 }\end{array}$ \\
\hline Ssa\#S31996856 & S31996856 & $2.0 \pm 1.1$ & $\begin{array}{l}\text { E3 ubiquitin-protein } \\
\text { ligase RNF128 }\end{array}$ \\
\hline Ssa\#STIR19643 & TC80514 & $-3.9 \pm 1.3$ & Myosin light chain 1-3 \\
\hline Ssa\#TC76471 & TC76471 & $-3.6 \pm 1.2$ & Tropomyosin-1 alpha chain \\
\hline Ssa\#AJ425777 & AJ425777 & $-2.7 \pm 1.3$ & $60 \mathrm{~S}$ ribosomal protein L34 \\
\hline Ssa\#STIR1 1900 & TC69277 & $-2.5 \pm 1.1$ & Myosin ic \\
\hline Ssa\#S35582711 & S35582711 & $-2.3 \pm 1.0$ & Tropomyosin-1 alpha \\
\hline Ssa\#S35505113 & S35505113 & $-2.2 \pm 1.1$ & $60 \mathrm{~S}$ ribosomal protein $\mathrm{L} 30$ \\
\hline Ssa\#FC072705 & FC072705 & $-2.1 \pm 1.1$ & $40 \mathrm{~S}$ ribosomal protein S10 \\
\hline Omy\#CX150249 & CX150249 & $-2.1 \pm 1.0$ & $60 \mathrm{~S}$ ribosomal protein L36 \\
\hline \multicolumn{4}{|l|}{ Lipid metabolism } \\
\hline Ssa\#CB509140 & CB509140 & $25.3 \pm 1.2$ & Fatty acid-binding protein \\
\hline Ssa\#S31963508 & S31963508 & $14.5 \pm 1.5$ & Apolipoprotein A-I \\
\hline Ssa\#STIR00045_2 & AY170327 & $5.2 \pm 1.0$ & PUFA elongase $5 \mathrm{~A}$ \\
\hline Ssa\#STIR00100_2 & CK887422 & $4.7 \pm 1.0$ & Delta-6 fatty acyl desaturase \\
\hline Omy\#S18154618 & S18154618 & $4.4 \pm 1.2$ & Glycolipid transfer protein \\
\hline Ssa\#STIR00093_4 & AF478472 & $4.3 \pm 1.1$ & Delta-5 fatty acyl desaturase \\
\hline \multicolumn{4}{|c|}{ Energy and mitochondrial activity/kinases } \\
\hline Ssa\#STIR00144_4 & TC64612 & $4.2 \pm 1.0$ & $\begin{array}{l}\text { Glyceraldehyde-3-phosphate } \\
\text { dehydrogenase }\end{array}$ \\
\hline Ssa\#STIR39924 & TC110855 & $2.6 \pm 1.2$ & Cytochrome P450 \\
\hline Ssa\#S32006874 & S32006874 & $2.3 \pm 1.1$ & $\begin{array}{l}\text { Peroxisomal membrane } \\
\text { protein } 11 \mathrm{C}\end{array}$ \\
\hline Ssa\#S30263228 & S30263228 & $2.4 \pm 1.1$ & Succinate dehydrogenase \\
\hline Ssa\#S35661441 & S35661441 & $2.0 \pm 1.0$ & Fructose-1.6-bisphosphatase 1 \\
\hline Ssa\#S32000347 & S32000347 & $-2.5 \pm 1.2$ & Hemoglobin subunit beta-1 \\
\hline
\end{tabular}


Table 4 Genes significantly different in mid intestine of fish fed PP diet (Continued)

\begin{tabular}{llll}
\hline Cellular transport & & & \\
\hline Ssa\#S30284157 & S30284157 & $23.6 \pm 1.2$ & Solute carrier family 22 \\
\hline Ssa\#STIR21606 & C83482 & $9.1 \pm 1.2$ & Solute carrier family 16 \\
\hline Ssa\#DW575876 & DW575876 & $7.2 \pm 1.3$ & Solute carrier family 39 \\
\hline Ssa\#STIR19539 & TC80341 & $4.6 \pm 1.0$ & Solute carrier family 31 \\
\hline Ssa\#STIR19539 & S35536215 & $2.8 \pm 1.0$ & Solute carrier family 25 \\
\hline Ssa\#S35454393 & S35454393 & $2.1 \pm 1.1$ & Solute carrier family 27 \\
\hline Omy\#TC172518 & TC172518 & $-2.2 \pm 1.1$ & Beta globin \\
\hline Ssa\#CK991045 & CK991045 & $-2.0 \pm 1.0$ & Hemoglobin subunit alpha
\end{tabular}

\section{Protein metabolism}

Feeding the PP diet the expression of genes involved in protein metabolism was significantly different compared to MP. For example, protein synthesis related genes including elongation factor, translation initiation factors 2 and $4 \mathrm{e}$ and ribosomal protein S6 kinase b were higher, while a number of $60 \mathrm{~S}$ ribosomal protein encoding genes were lower relative to MP fed fish. Protein degradation encoding genes were more highly expressed as shown by lysosomal proteases, cathepsins A, C, and Z, ubiquitin proteasome route (UbP) of proteolysis, and proteasome subunits $\alpha 5, \alpha 6, \alpha 7$ and $\beta 7$. Genes involved in targeting of proteins for degradation in the UbP were also higher including ubiquitin conjugating enzyme E2 and ubiquitin E3 ligases. Genes encoding the structural proteins troponin, tubulin, titin, actin and keratin were all found to have a higher expression level whereas a number of myosin mRNAs were lower in expression.

\section{Lipid metabolism}

A higher transcript level of genes involved in lipid transport and metabolism was observed, with higher transcription of fatty acid-binding protein, apolipopro- tein A-I, apolipoprotein B and delta- 6 fatty acyl desaturase, delta-5 fatty acyl desaturase, PUFA elongase $5 \mathrm{~A}$ and glycolipid transfer protein, respectively.

\section{Energy and mitochondrial activity/kinases}

There was an induction of many genes related to energy metabolism in pathways such as glycolysis (glyceraldehyde-3 phosphate dehydrogenase), the tricarboxylic acid cycle (succinate dehydrogenase) and gluconeogenesis (fructose 1-6- bisphosphate) which were expressed at a higher level in PP fed fish relative to the MP fed fish.

\section{Cellular transport}

Transport of solutes into and from a cell is an energy demanding process. Genes involved in membrane transport were higher in expression in fish fed the PP diet, and included a number of solute carrier family members such as SCF22 (organic cation transporter), SCF 27 (fatty acid transporter), SCF 25 (mitochondrialphosphate carrier), SCF 39 (zinc transporter), SCF 16 (monocarboxylic acid transporter), and SCF 31 (copper transporter). Two genes encoding haemoglobin subunits (hemoglobin subunit alpha-4 and hemoglobin subunit beta-1) and beta

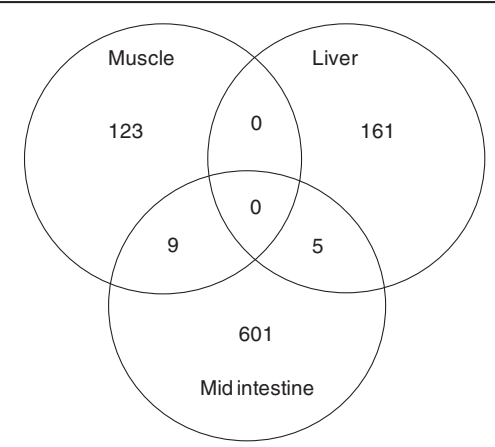

Higher expression in PP fed fish

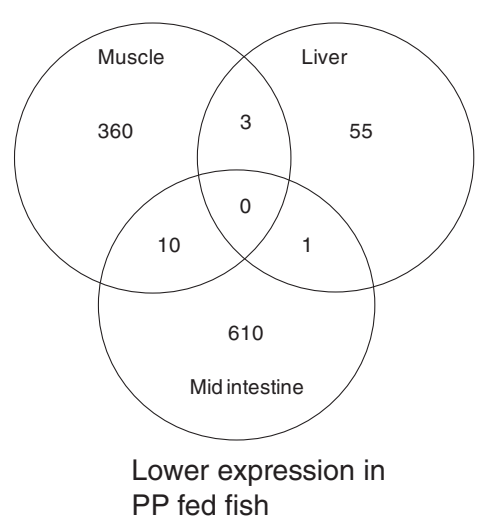

PP fed fish

Figure 1 Venn diagram showing numbers of genes identified as expressed at different levels by microarray analysis. Summary of numbers of genes higher and lower expressed. The genes presented are all significantly different in expression $(p<0.05)$ with $>2$ fold change in expression. 
Table 5 Genes significantly different in liver of fish PP diet

\begin{tabular}{|c|c|c|c|}
\hline Probe name $^{1}$ & $\mathrm{ACC}^{2}$ & $\mathrm{FC} \pm \mathrm{SEM}^{3}$ & Identity $^{4}$ \\
\hline \multicolumn{4}{|c|}{ Immune function and stress response } \\
\hline Ssa\#S35601811 & S35601811 & $2.7 \pm 1.0$ & MPV17 protein \\
\hline Ssa\#gi156446662 & EF579742 & $2.4 \pm 1.1$ & MyD88 \\
\hline Omy\#S18150823 & S18150823 & $2.2 \pm 1.1$ & Amine oxidase \\
\hline Ssa\#STIR13675 & TC71772 & $2.0 \pm 1.0$ & CD209f \\
\hline Ssa\#CK874360 & CK874360 & $2.0 \pm 1.1$ & Heat shock 70 \\
\hline Ssa\#STIR36546 & TC105929 & $-2.8 \pm 1.1$ & C-type MBL-2 protein \\
\hline Ssa\#NP797925 & NP797925 & $-2.4 \pm 1.1$ & MHC class I alpha 2 \\
\hline Ssa\#STIR04816 & NM_001140849 & $-2.4 \pm 1.2$ & Hepcidin \\
\hline Ssa\#NP9934311 & NP9934311 & $-2.2 \pm 1.1$ & T cell receptor alpha \\
\hline Ssa\#S48440415 & S48440415 & $-2.2 \pm 1.3$ & SMAD3 \\
\hline Ssa\#S35663823 & S35663823 & $-2.1 \pm 1.1$ & Complement $\mathrm{clq}$ \\
\hline \multicolumn{4}{|c|}{ Cell proliferation and apoptosis } \\
\hline Ssa\#CA041082 & CA041082 & $2.6 \pm 1.2$ & Transforming growth factor beta receptor \\
\hline Ssa\#S35486979 & S35486979 & $2.5 \pm 1.0$ & Cell death activator CIDE-3 \\
\hline Ssa\#S35559076 & S35559076 & $2.3 \pm 1.0$ & Angiopoietin-related protein 4 \\
\hline Ssa\#S30276711 & S30276711 & $2.3 \pm 1.1$ & Activin receptor type-1B \\
\hline Ssa\#S35582821 & S35582821 & $2.3 \pm 1.0$ & Serine protease HTRA1 \\
\hline Ssa\#STIR31305 & TC98147 & $2.2 \pm 1.1$ & Annexin A3 \\
\hline Omy\#S18150823 & S18150823 & $2.2 \pm 1.0$ & Amine oxidase \\
\hline \multicolumn{4}{|c|}{ Protein metabolism } \\
\hline Ssa\#DW574268 & DW574268 & $2.4 \pm 1.1$ & Ribosomal protein S18 \\
\hline Ssa\#STIR03071 & BT048999 & $2.3 \pm 1.1$ & Proteasome beta type 3 \\
\hline Ssa\#KSSb2684 & KSSb2684 & $2.2 \pm 1.2$ & Peptidyl-prolyl cis-trans isomerase \\
\hline Ssa\#STIR16404 & TC75662 & $2.2 \pm 1.1$ & Calpain \\
\hline Ssa\#STIR04151 & NM_001141015 & $2.1 \pm 1.0$ & Ribosomal protein 139 \\
\hline
\end{tabular}

globin, however, were found to have a lower relative expression level.

\section{Genes expressed at different levels in liver}

Several biological processes were significantly different in liver that can be related to immune parameters, stress responses, and protein and lipid metabolism, with key genes shown in Table 5.

\section{Immune and stress response}

Genes encoding proteins involved in innate immunity such as complement c1q, C-type MBL-2 and a dendritic cell specific lectin CD209f which binds mannose carbohydrate molecules, and hepcidin a major liver associated antimicrobial peptide were lower in PP fed fish. A limited number of genes related to adaptive immunity were also found to be expressed at different levels, with MHC class I and SMAD 3 lower in expression level, whereas MyD88 was higher in fish fed the PP diet relative to MP fed fish. Moreover, genes involved in the oxidative response (MPV17 protein, amine oxidase and heat shock cognate $70 \mathrm{kDa}$ protein) were also higher in fish fed the PP diet.

\section{Cell proliferation and apoptosis}

The PP diet stimulated/modified hepatic cell turnover as indicated by higher expression of serine protease HTRA1 and annexin A3 and the stimulation of apoptotic processes through genes involved in TGF beta pathways (cell death activator CIDE-3 and angiopoietin-related protein 4).

\section{Protein metabolism}

Hepatic protein metabolism was clearly stimulated in PP fed fish since all genes significantly different in expression were higher in these fish, including ribosomal protein S18a, ribosomal protein 139 and peptidyl-prolyl cis-trans isomerise. Similarly genes involved in protein degradation were more highly expressed as seen with the non-lysosomal protein calpain and the proteasome subunit $\beta 3$. 
Table 6 Genes significantly different in skeletal muscle of fish PP diet

\begin{tabular}{|c|c|c|c|}
\hline Probe name $^{1}$ & $\mathrm{ACC}^{2}$ & $\mathrm{FC} \pm \mathrm{SEM}^{3}$ & Identity ${ }^{4}$ \\
\hline \multicolumn{4}{|l|}{ Immune function } \\
\hline Ssa\#STIR12634 & TC70300 & $5.0 \pm 1.2$ & Vig-2 \\
\hline Ssa\#STIR00067_2 & U66477 & $3.2 \pm 1.3$ & Interferon inducible Mx protein \\
\hline Ssa\#CK894557 & CK894557 & $-11.2 \pm 1.4$ & MHC class Ib antigen \\
\hline Ssa\#STIR00132_2 & NM_001140254 & $-7.4 \pm 1.3$ & Tumor necrosis alpha-induced protein 2 \\
\hline Omy\#NP565601 & NP565601 & $-6.4 \pm 1.4$ & T-cell receptor beta \\
\hline Ssa\#S31982089 & S31982089 & $-5.4 \pm 1.1$ & Platelet-activating factor receptor \\
\hline Ssa\#STIR12498 & TC70105 & $-4.6 \pm 1.2$ & Y-ip (CXCL10) \\
\hline Ssa\#S48440415 & S48440415 & $-3.4 \pm 1.1$ & SMAD3 \\
\hline Omy\#S15331473 & S15331473 & $-3.2 \pm 1.2$ & Interferon-inducible protein Gig2-like \\
\hline Ssa\#S35544087 & S35544087 & $-3.1 \pm 1.3$ & $\begin{array}{l}\text { B-cell CLL/lymphoma } 7 \text { protein } \\
\text { family member B }\end{array}$ \\
\hline Ssa\#STIR13083 & TC70912 & $-3.6 \pm 1.0$ & SAMHD1 \\
\hline Omy\#S18153399 & S18153399 & $-2.4 \pm 1.1$ & CD80 \\
\hline Ssa\#KSS5035 & KSS5035 & $-2.2 \pm 1.2$ & Interferon regulatory factor 2-binding protein \\
\hline Ssa\#STIR00071_3 & DW580947 & $-2.3 \pm 1.1$ & Interferon -induced protein 35 \\
\hline Ssa\#STIR08451 & TC64790 & $-2.2 \pm 1.2$ & Heat shock protein 47 \\
\hline Ssa\#S35480903 & S35480903 & $-2.0 \pm 1.2$ & Heat shock protein 30 \\
\hline Ssa\#STIR29454 & TC95297 & $-2.1 \pm 1.1$ & Beta defensin 1 \\
\hline
\end{tabular}

\section{Cell proliferation and apoptosis}

\begin{tabular}{|c|c|c|c|}
\hline Ssa\#S35602638 & S35602638 & $3.7 \pm 1.4$ & Tripartite motif 39 \\
\hline Ssa\#TC110067 & TC110067 & $3.5 \pm 1.5$ & Cell death inducing protein \\
\hline Ssa\#STIR08668 & TC65039 & $3.1 \pm 1.1$ & Bh3 interacting domain death agonist \\
\hline Ssa\#STIR12507 & TC70118 & $3.0 \pm 1.3$ & Syndecan 4 \\
\hline Ssa\#STIR02208 & BT049868 & $-38.6 \pm 1.2$ & Caspase 14 \\
\hline Ssa\#S35559333 & S35559333 & $-4.1 \pm 1.3$ & Ankyrin repeat domain-containing protein 54 \\
\hline Omy\#TC151190 & TC151190 & $-2.9 \pm 1.2$ & Nucleostemin \\
\hline Ssa\#S35550715 & S35550715 & $-2.8 \pm 1.2$ & $\begin{array}{l}\text { Growth hormone-inducible } \\
\text { transmembrane protein }\end{array}$ \\
\hline Ssa\#S35585784 & S35585784 & $-2.6 \pm 1.1$ & Caspase-8 \\
\hline Ssa\#KSS5035 & KSS5035 & $-2.4 \pm 1.2$ & $\begin{array}{l}\text { Interferon regulatory factor 2-binding } \\
\text { protein 2-B }\end{array}$ \\
\hline \multicolumn{4}{|c|}{ Protein metabolism } \\
\hline Ssa\#S35682089 & S35682089 & $4.2 \pm 1.3$ & Ubiquitin-like protein 1 \\
\hline Ssa\#STIR17445 & TC77227 & $2.6 \pm 1.3$ & Acta1 protein \\
\hline Ssa\#STIR21465 & TC83266 & $2.5 \pm 1.2$ & Actin-binding \\
\hline Ssa\#STIR03710 & BT048358 & $2.0 \pm 1.2$ & Proteasome subunit beta type- 9 \\
\hline Ssa\#STIR00115_4 & BT045917 & $2.0 \pm 1.2$ & Tropomyosin-1 alpha chain \\
\hline Ssa\#S32008331 & S32008331 & $-3.6 \pm 1.7$ & 40 S ribosomal protein S16 \\
\hline Ssa\#CL224Ctg1 & NM_001140473 & $-2.8 \pm 1.5$ & $\begin{array}{l}\text { Receptor-interacting serine/threonine-protein } \\
\text { kinase } 4\end{array}$ \\
\hline Omy\#CX150460 & CX150460 & $-2.7 \pm 1.1$ & 60 S ribosomal protein L27 \\
\hline Omy\#S15320960 & S15320960 & $-2.6 \pm 1.1$ & Cathepsin D \\
\hline Ssa\#TC111443 & TC111443 & $-2.5 \pm 1.1$ & Serine/threonine-protein kinase 35 \\
\hline Ssa\#FC072705 & FC072705 & $-2.3 \pm 1.0$ & $40 \mathrm{~S}$ ribosomal protein $\mathrm{S} 10$ \\
\hline Ssa\#S35583213 & S35583213 & $-2.1 \pm 1.2$ & Serine/threonine-protein kinase PINK1 \\
\hline Ssa\#S35591236 & S35591236 & $-2.1 \pm 1.1$ & $\begin{array}{l}\text { Histidine triad nucleotide-binding } \\
\text { protein } 3\end{array}$ \\
\hline
\end{tabular}


Table 6 Genes significantly different in skeletal muscle of fish PP diet (Continued)

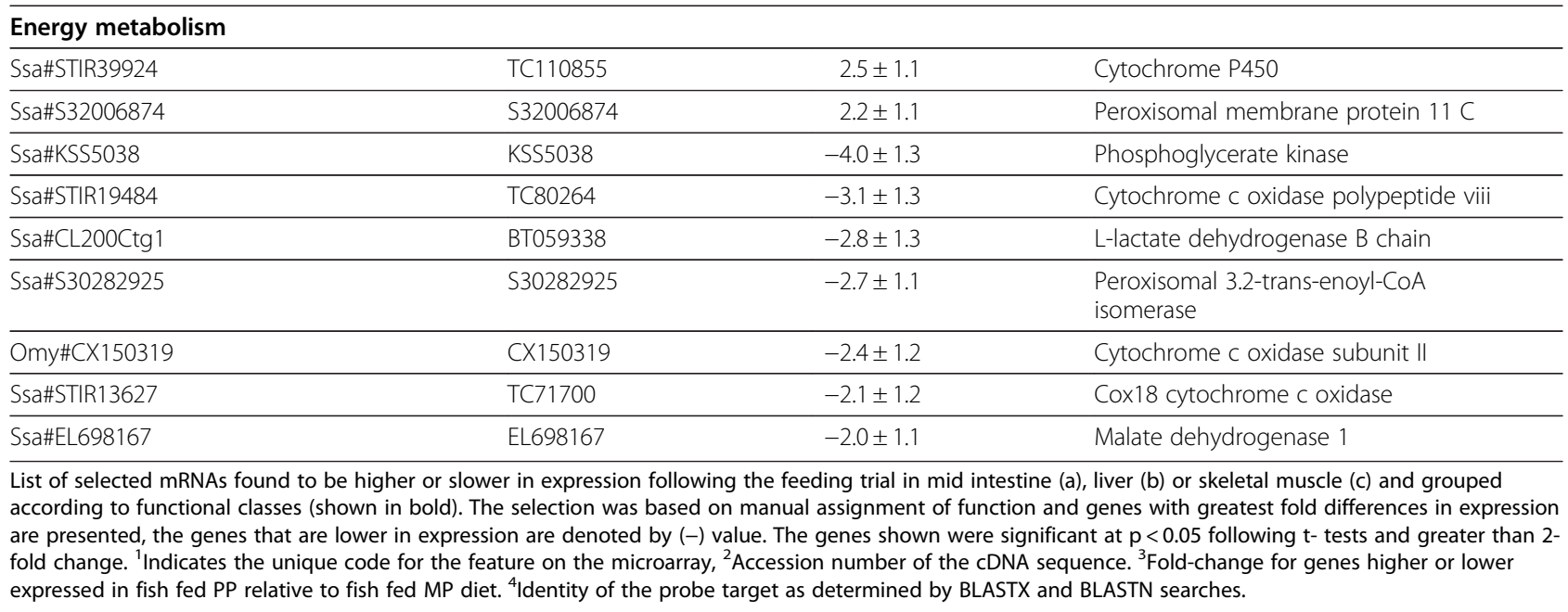

\section{Genes expressed at different levels in skeletal muscle}

The GO analysis showed a number of processes to be significantly different in skeletal muscle that can be related to protein metabolism, immune function and energy metabolism (Table 6).

\section{Immune and stress response}

Regarding the innate immune status, PP fed fish showed lower expression level of inflammatory related genes such as platelet-activating factor receptor, SAMHD1, tumor necrosis alpha-induced protein 2 , and the antimicrobial peptide beta defensin 1 . Likewise, fish fed the PP diet showed a suppression of genes involved in the adaptive immune response, i.e. TCR $\beta$, MHC class I, SMAD 3, CD80 (a T cell activator). Interferon $\gamma$ induced proteins $\gamma$-ip (CXCL10), Gig2-like and both interferoninduced protein 35 and IRF2-binding protein were also lower in fish fed the PP diet. In contrast, Mx and Vig-2 which are responsive to type I interferon were higher expressed in PP compared to MP. Lastly, the stress induced genes HSP 30 and 47 were lower in expression in PP fed fish relative to MP fed fish.

\section{Cell proliferation and apoptosis}

Genes involved in cell proliferation were lower expressed in the PP fed fish, including ankyrin repeat domain-containing protein 54, nucleostemin and growth hormone-inducible transmembrane protein. Several genes involved in apoptosis were found to be higher such as cell death inducing protein and bh3 interacting domain death agonist although in contrast whereas both caspase 8 and 14 showed lower transcript levels in the PP fed fish.

\section{Protein metabolism}

Genes involved in protein synthesis such as several $60 \mathrm{~S}$ and $40 \mathrm{~S}$ ribosomal proteins were lower in expression in skeletal muscle of PP fed fish. A number of enzyme genes that modify essential amino acids (eg serine/threonine-protein kinase PINK1, serine/threonine-protein kinase 35, receptor-interacting serine/threonine-protein kinase 4 amongst others) were also lower in expression. Likewise, a major lysosomal peptidase, cathepsin D was lower in expression in PP fed fish, however, two components of the UbP were higher expressed in PP (ubiquitin-like protein precursor and proteasome subunit beta type-9).

Genes encoding proteins involved in muscle structure and physiology (acta1 protein, actin-binding homolog 1a and tropomyosin-1 alpha chain) were also more highly expressed in skeletal muscle of fish fed the PP diet.

\section{Energy metabolism}

Genes related to energy metabolism were transcriptionally modified with peroxisomal membrane protein $11 \mathrm{C}$ and cytochrome $\mathrm{P} 450$ being higher in expression whereas cytochrome c oxidases (COX2, 8 and 18) were found to be lower in PP fed fish compared to MP fed fish. In addition genes involved in glycolysis (phosphoglycerate kinase 1 and L-lactate dehydrogenase B chain) and gluconeogenesis (malate dehydrogenase 1) were found to be expressed lower in PP fed fish.

\section{Co-regulated genes}

Only a small number of genes were co regulated between tissues following the feeding trial. No genes were significantly higher or lower regulated in all the tissues in this experiment. The greatest co regulation was observed between mid intestine and skeletal muscle, with 9 genes significantly higher and 10 genes significantly lower in PP compared to MP. Genes that were more highly expressed in mid intestine and liver of fish fed the PP diet compared to the MP diet play a role in energy metabolism, such as 
a

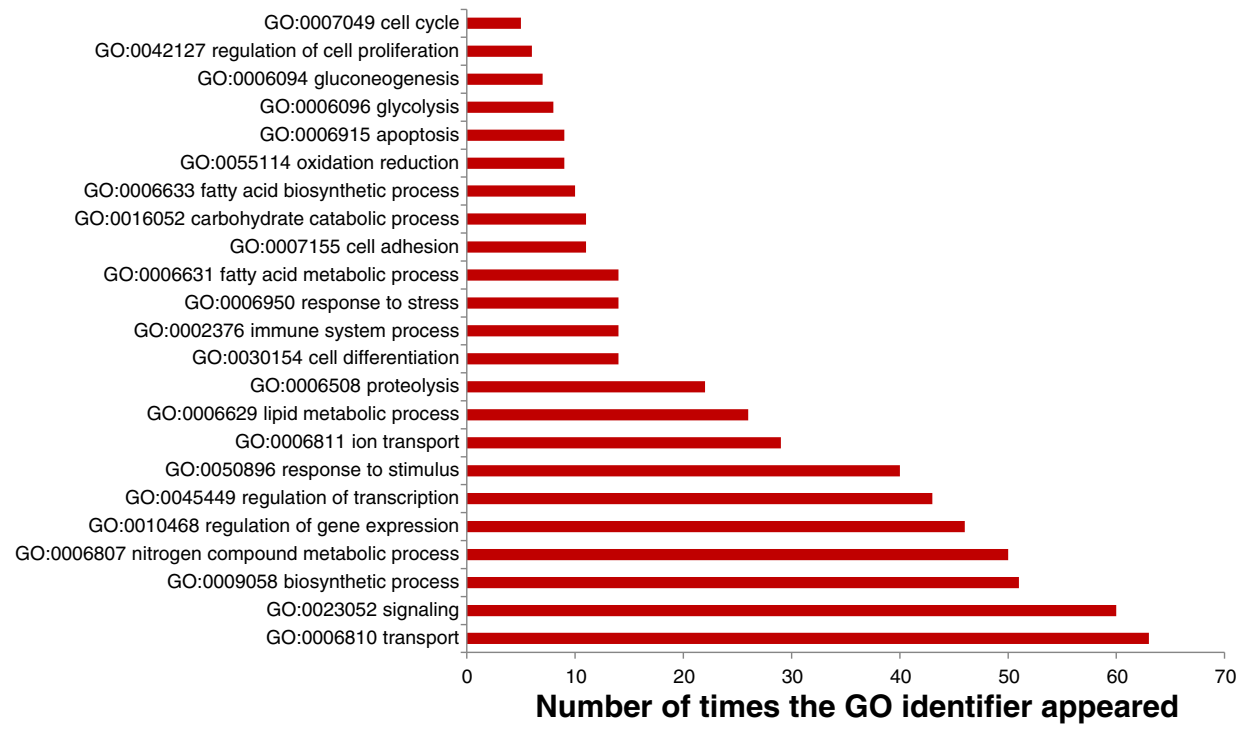

b

\footnotetext{
GO:0015031 protein transport

GO:0006950 response to stress

GO:0050896 response to stimulus

GO:0019538 protein metabolic process
}

GO:0051171 regulation of nitrogen compound metabolic..

GO:0006355 regulation of transcription, DNA-dependent

GO:0071841 cellular component organization or biogenesis..

GO:0044260 cellular macromolecule metabolic process

GO:0006810 transport

GO:0051179 localization

GO:0023052 signaling

GO:0008152 metabolic process

Number of times the GO identifier appeared

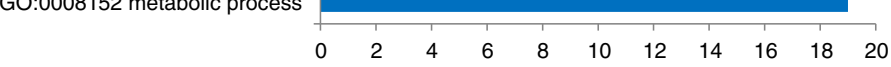

Number of times the GO identifier appeared

C

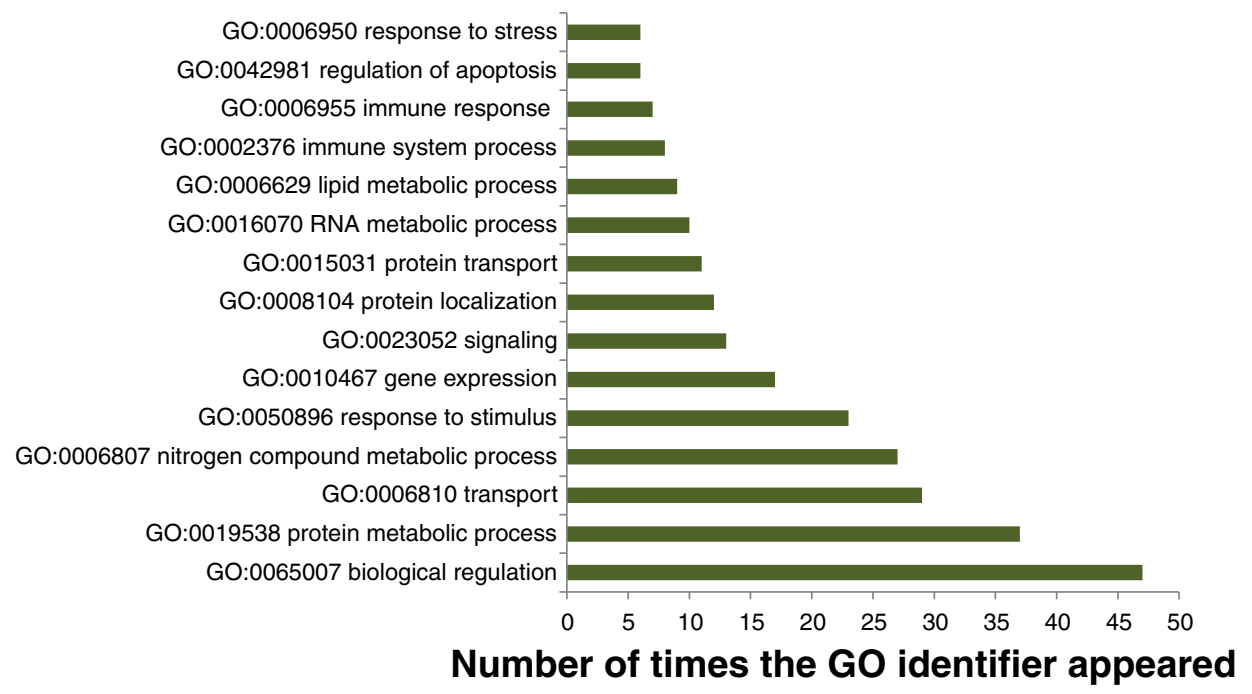

Figure 2 (See legend on next page.) 
cytochrome $\mathrm{P} 450$, a membrane-associated protein located in the inner membrane of mitochondria and peroxisomal membrane protein $11 \mathrm{C}$ that induces peroxisomal proliferation proteins involved in the pentose phosphate pathway. Genes that showed lower expression in mid intestine and liver have a role in protein synthesis (40 S ribosomal protein S10) and in the immune response, such as SAMHD1 a nuclease involved in innate immune responses by acting as a negative regulator of the cellintrinsic antiviral response. Five genes were higher expressed in both intestine and liver of fish fed the PP diet, including immune related genes, such as CD209f and MyD88 and only 1 gene (complement c1q) showed lower expression in both tissues. Skeletal muscle and liver did not have any higher expressed gene in common and only 3 genes (membrane-bound O-acyltransferase domaincontaining protein 7, SMAD 3 and the non annotated gene (NP_998306) were significantly lower between these two tissues (Figure 2; full list of genes expressed at different levels is given in supplementary Table 1).

\section{Confirmation of expression by real time PCR}

Real time PCR analysis was performed on a number of genes for each tissue to confirm microarray data (Table 7). The real time PCR expression data was normalized with HPRT1 as the expression of this housekeeping gene was not found modulated by microarray analysis. For all genes the expression pattern showed the same trend between microarray and real time PCR analysis (Figure 3).

\section{Discussion}

With the continual expansion of aquaculture of piscivorous fish there is a global requirement to reduce the dependence on wild caught fish for the generation of fishmeal and fish oil. There are a number of studies that have explored the transcriptional response to plant and vegetable oil replacements in fish diets, often when $100 \%$ replacement experimental diets are used results in reduced growth $[24,25]$. When both proteins and oils were replaced [24] in rainbow trout microarray analysis of liver indicated processes such as protein metabolism and cell cycle being altered, however the reasons for these changes could either have been combined effect of lowered essential fatty acids or changes in amino acid profile. There is also growing body of work demonstrating the genotype diet interaction in rainbow trout [25-27] and Atlantic salmon [28], with the latter concluding transcription of key metabolic regulators that respond to plant based feeds depend on the fish's genotype. Commercial salmon feed formulations partially replace fish meal with plant derived proteins, with varying effects on fish physiology and performance including fish growth and food conversion [24,29]. This paper examined the physiological and performance effects with transcriptional responses in mid intestine, liver and skeletal muscle in salmon to a post smolt feed containing high levels of plant derived proteins with low fishmeal content compared to a low plant protein-high fishmeal diet. The tissues examined play different physiological roles in the fish all of which may be affected by dietary changes as reflected in the different response profiles seen in these tissues. In common with a number of other transcriptomic studies on nutritional effects (where extreme dietary manipulations are avoided) the impact of the different diets appears quite subtle suggesting limited changes to physiological and metabolic pathways [30]. Although, in general, the scale of gene response is quite low, distinct changes in all tissues examined do indicate that there are responses occurring as a result of the dietary components.

When interpreting the findings it is important to take a comparative holistic approach whereby apparent down regulation of genes in fish fed one diet may in fact be the result of up regulation in fish fed the other dietary treatment and vice versa. In this paper the expression is analysed relative to the marine profile (MP) diet.

\section{Histological changes}

The occurrence of histological changes was very similar for fish fed either diet, with low frequencies observed for the majority of parameters measured. The main histological observation was a mild fatty change in liver, which is considered normal under intensive rearing conditions. This anomaly appeared to have no clinical effect, and was not prevalent for either dietary group. Although there was a higher incidence of peri-biliar duct infiltration in liver of fish fed the MP diet no other histological changes were observed to indicate an inflammatory response. This reduced infiltration in the liver by the biliary ducts may be related to the altered immune gene expression in the liver. In mammals viral infections can result in biliary atresia [31] and specifically can be related to immune related injury to bile ducts following infiltration of $\mathrm{CD} 4^{+} \mathrm{T}$ and production of interferon $\gamma$ [32]. At this stage we are unable to tell if the reduction in the structures is a direct result of the nutritional components or due to the altered hepatic 
Table 7 Primers used for real time PCR for expression analysis, Acc is accession number from NCBI

\begin{tabular}{|c|c|c|c|c|c|c|}
\hline Gene name & Primer name & Primer sequence(5-prime to 3-prime) & Acc & Product size & Ann $T$ & Tissue \\
\hline \multirow[t]{2}{*}{ Fabp2 } & FatF & GCTCTGTACTAGCTCTCCTCCC & CB509140 & $156 \mathrm{bp}$ & $55^{\circ} \mathrm{C}$ & Mid intestine \\
\hline & FatR & GGCGTACAGTTTGACTATGCAC & & & & \\
\hline \multirow[t]{2}{*}{ Caspase-14 } & Cas14F & CGATTATACACCCGGACTATGG & S35582566 & $155 p$ & $55^{\circ} \mathrm{C}$ & Mid intestine \\
\hline & Cas14R & CCTATCAAGTGTGAATCCATGC & & & & \\
\hline \multirow[t]{2}{*}{ TCR alpha } & TCRaF & GGAAGACTCTGCTCTGTACCAC & U50991 & $147 \mathrm{bp}$ & $55^{\circ} \mathrm{C}$ & Mid intestine \\
\hline & TCRaR & GCTGTGGTATTTCTTGACTTC & & & & \\
\hline \multirow[t]{2}{*}{ IgM heavy chain } & $\operatorname{lgMF}$ & GCTTATAGCCATAGTACTACTG & S18892409 & $169 \mathrm{bp}$ & $55^{\circ} \mathrm{C}$ & Mid intestine \\
\hline & IgMR & GCATAGCTGCCCCATATCGC & & & & \\
\hline \multirow[t]{2}{*}{ Tpm1 } & Trop1F & CGAAGATGAGAGAGATAAAGTGC & TC76471 & $134 \mathrm{bp}$ & $55^{\circ} \mathrm{C}$ & Mid intestine \\
\hline & Trop1R & CCTCCTCAACCAGCTGGATACG & & & & \\
\hline \multirow[t]{2}{*}{ RFC3 } & ReplF & GCTGACTCACTGCATTCCTCCTG & S34421775 & $163 \mathrm{bp}$ & $55^{\circ} \mathrm{C}$ & Mid intestine \\
\hline & RepIR & GAAGGCCTCTAGGTGGTAAATGG & & & & \\
\hline \multirow[t]{2}{*}{ HTRA1 } & HTRA1F & GGTCATCTTCATACAGAGAGG & S35582821 & $152 \mathrm{bp}$ & $55^{\circ} \mathrm{C}$ & Liver \\
\hline & HTRA1R & GCTTAGAGAATACCATCTTGC & & & & \\
\hline \multirow[t]{2}{*}{ TGF beta receptor } & TGBF & CCACAAGAAGCCAGCTGTCAG & gi|209735249 & $135 \mathrm{bp}$ & $55^{\circ} \mathrm{C}$ & Liver \\
\hline & TGFBR & CTAGCCAGGTATCTCTATCATGG & & & & \\
\hline \multirow[t]{2}{*}{ MRPS18A } & $28 \mathrm{SF}$ & CCATTGATTCAGTGAAGCCCATC & DW574268 & $158 \mathrm{bp}$ & $55^{\circ} \mathrm{C}$ & Liver \\
\hline & $28 \mathrm{SR}$ & CCTGCTGTGAGTTGACATGC & & & & \\
\hline \multirow[t]{2}{*}{ Timd2 } & TcellF & CCATGGACAACCACACACACTG & CA368982 & $141 \mathrm{bp}$ & $55^{\circ} \mathrm{C}$ & Liver \\
\hline & TcellR & CCAGTAGAATGGACACCAGGATC & & & & \\
\hline \multirow[t]{2}{*}{ Hepcidin I } & HepF & GCTTCTGCTGCAAATTCTGAGG & gi|209736931 & $157 \mathrm{bp}$ & $55^{\circ} \mathrm{C}$ & Liver \\
\hline & HepR & GTACAAGATTGAGGTTGTGCAG & & & & \\
\hline \multirow[t]{2}{*}{ TCR alpha } & TCRaF & GGAAGACTCTGCTCTGTACCAC & U50991 & $147 \mathrm{bp}$ & $55^{\circ} \mathrm{C}$ & Liver \\
\hline & TCRaR & GCTGTGGTATTTCTTGACTTC & & & & \\
\hline \multirow[t]{2}{*}{ CDIP } & CellF & CCATGTCTGAGACCTACTCTATG & TC110067 & $243 \mathrm{bp}$ & $55^{\circ} \mathrm{C}$ & Skeletal muscle \\
\hline & CellR & GATAGTCACTTGATGTCCAGTG & & & & \\
\hline \multirow[t]{2}{*}{ acta1 protein } & ActaF & CCTGTAAACTGTGAATGCGTC & TC77227 & $156 \mathrm{bp}$ & $55^{\circ} \mathrm{C}$ & Skeletal muscle \\
\hline & ActaR & CCAAAGTITTATATCAGCTGC & & & & \\
\hline \multirow[t]{2}{*}{ TGF beta 1} & TGF1bF & GCTCGGAGTGTGAGACAGAACTG & S15319964 & $187 \mathrm{bp}$ & $55^{\circ} \mathrm{C}$ & Skeletal muscle \\
\hline & TGF1bR & CACTTGACGCAACAGAAACACTCC & & & & \\
\hline \multirow[t]{2}{*}{ RT1-CE5 } & $\mathrm{MHC} 1 \mathrm{bF}$ & GGAAAGATCTCCTGAAGACTTGAG & CK894557 & $101 \mathrm{bp}$ & $55^{\circ} \mathrm{C}$ & Skeletal muscle \\
\hline & MHC1bR & CGTTTATGAGAAGTTCAGC & & & & \\
\hline \multirow[t]{2}{*}{$60 \mathrm{~S}$ rib prot } & $60 \mathrm{SF}$ & GCTTCTTACCATGGTTCTTCAG & DR695852 & $140 \mathrm{bp}$ & $55^{\circ} \mathrm{C}$ & Skeletal muscle \\
\hline & $60 S R$ & GGTCAAGATCCCATCCACCATC & & & & \\
\hline \multirow[t]{2}{*}{ Heat shock protein 30} & HeatF & CCATCCAACCAGTCTCCTACAAGC & EG804126 & $303 \mathrm{bp}$ & $55^{\circ} \mathrm{C}$ & Skeletal muscle \\
\hline & HeatR & CCTCCTCAGCAGATAATGGATTC & & & & \\
\hline \multirow[t]{2}{*}{ Hprt } & HprtF & CCGCCTCAAGAGCTACTGTAAT & EG866745 & $255 \mathrm{bp}$ & $55^{\circ} \mathrm{C}$ & All tissues \\
\hline & HprtR & GTCTGGAACCTCAAACCCTATG & & & & \\
\hline
\end{tabular}

immune gene expression in between the two diets. The distal intestine is often the target organ for anti-nutriental factors, in particular those present in SBM and pea protein concentrate [22], inducing histological changes including shortening of simple and complex mucosal folds with widening of central stroma, inflammatory cell infiltration in the submucosa and lamina propria with a mixed leukocyte population [33,34]. In this study both dietary groups presented fish with distal intestine anomalies but with low frequencies, and no significant difference between diets. These results together with those reported by Sanden et al. (2005) [35] indicate soybean products, including the alcohol soluble fraction, may be used within formulation constraints without inflicting gross histopathological anomalies in the intestine of Atlantic salmon. 


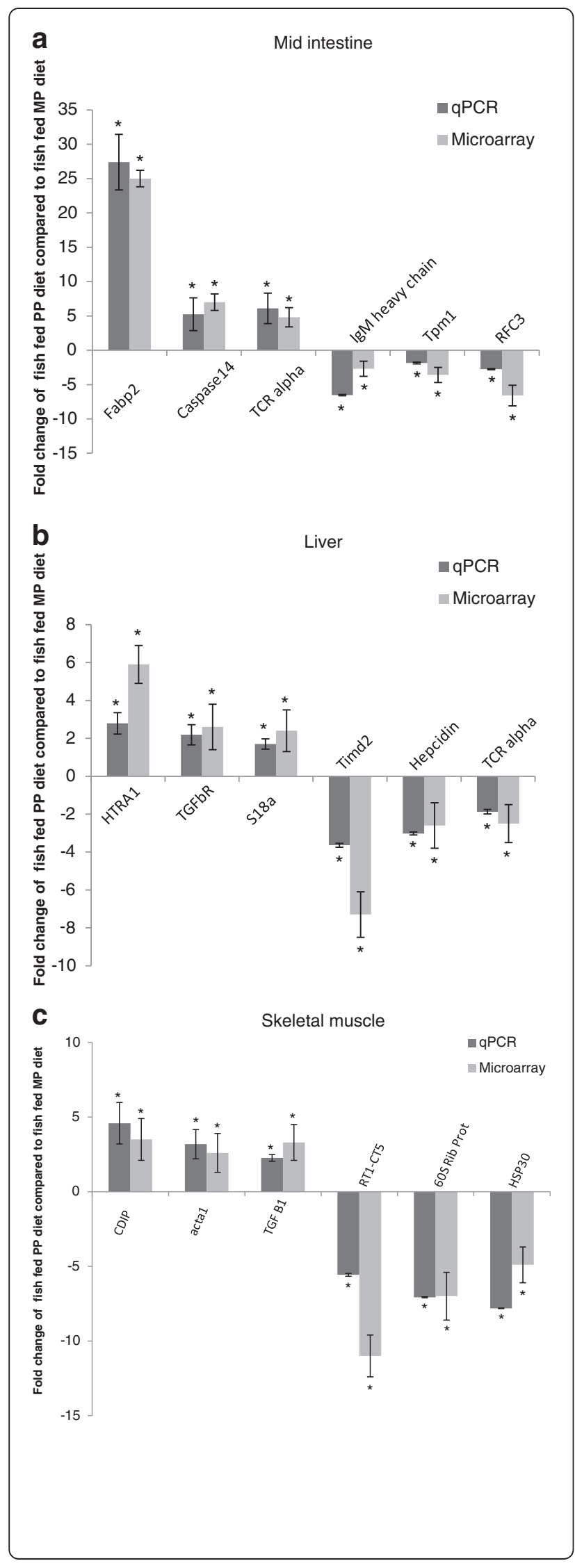

Figure 3 Quantitative real-time PCR confirmation of genes expressed at different levels in mid intestine (a), liver (b) and skeletal muscle (c) of fish fed the PP diet compared to fish fed the MP diet for 6 genes identified by microarray analysis. Bars represent mean \pm standard error of five fish, asterisks indicate significant $(p<0.05)$ differences. The genes chosen for the intestine were: Fatty acid-binding protein (Fabp2), Caspase-14 precursor, TCR alpha, IgM heavy chain, Tropomyosin-1 alpha chain (Tpm1) and Replication factor $C$ subunit 3 (RFC3). The genes selected for the liver were: Serine protease HTRA1, TGF beta receptor, $28 \mathrm{~S}$

Ribosomal protein S18a (MRPS18A), T-cell immunoglobulin and mucin domain (Timd2), hepcidin I and TRC alpha. The gene chosen for the skeletal muscle were: cell death inducing protein (CDIP), acta1 protein, Transforming growth factor beta-1 (TGF beta 1), MHC class Ib antigen (RT1-CE5), 60Sribosomal protein L6 (60 S rib prot) and Heat shock protein 30.

\section{Transcriptome changes in the mid intestine}

The fish intestine has multiple functions which will be the first to respond to changes in nutritional intake; particularly digestion and absorption of nutrients and immune responsiveness to ingested pathogens, antigens and new antigens generated by the gut flora via gut associated lymphoid tissue [36]. The intestine contains three distinct regions: the proximal intestine containing pyloric caeca, the mid and distal intestine. Nutrient absorption occurs in all regions via enterocytes, by passive and facilitated diffusion and active transport [37], with the highest rates of uptake in the proximal section $[37,38]$. The intestine of piscivorous fish can be particularly sensitive to plant derived ANFs and non-starch polysaccharides (NSP) in feed, resulting in altered permeability in trout feed 44\% 44\% SBM [7,39] and enteritis in the distal intestine of salmon given a high dietary inclusion of SBM [33]. The inflammation/enteritis may be similar to a hypersensitivity reaction $[33,40]$. Often these effects are temporary and quickly disappear when the intestinal tract is no longer exposed to the ANFs $[11,33,41]$.

Processing of plant products for fish feed is under continual improvement and some current plant derived protein concentrates have very low contaminating factors or botanical impurities. In addition knowledge of ANF containing plant feed materials has increased to the point where commercial feed formulations permit plant derived proteins at acceptable inclusion levels where no negative health effects or impacts on growth and performance occur. This was confirmed in the current study by the histology assessment where no gross morphological changes associated with plant ANFs were observed. In addition there was no difference in growth or feed utilisation efficiency during the feeding period, where a doubling of weight was achieved. However there were more subtle changes to biological processes that were not apparent during the classical physiological 
evaluation but were detected by global transcriptomic analysis. In this trial the mid intestine showed the greatest transcriptome response of the tissues studied, reflecting the sensitivity of the intestinal cells to dietary factors. Processes modified in the intestine were related to immune parameters, cell proliferation, apoptosis, protein metabolism, energy metabolism, transport and lipid metabolism.

Fish fed the PP diet showed higher expression of genes involved in inflammation suggesting a possible dysfunction in immune regulation. Our findings support previous studies on gut intraepithelial and systemic $\mathrm{T}$ cells in fish which showed rainbow trout IELs are rich in T cells $[10,42]$. Additionally the expression of TSC22D3, a regulator of $\mathrm{T}$ cell receptor mediated cell death, was found higher in PP, this protein may be induced by glucocorticoids $[43,44]$ activated by components in the PP diet. Together these results support previous reports that trace levels of substances with allergenic properties may cause expression of genes indicative of a hypersensitivity reaction in the intestine [45].

Interestingly genes involved in the inflammatory response were both higher and lower expressed in PP compared to MP. In particular genes involved in NF- $\kappa \mathrm{B}$ pathway were induced such as the signalling adaptor molecule MyD88 and the inhibitory proteins of the IkB family, NF-kB1 p105 which sequesters NF $k$ B in an inactive form in the cytoplasm [46]; inhibition of this pathway results in the production of proinflammatory cytokines [47]. MyD88 is also part of the signalling pathway that induces type I IFNs through the interaction of the MyD88-TRAF6-IRF7 complex [48]. IRF1 [49] had higher expression in fish fed the PP diet, this transcription factor may have activated interferon responsive genes in PP fed fish including Mx [50], virus induced gene (vig) -2 [51] and a virus induced TRIM protein [52]. PP fed fish also had higher expression of (SOCS)-7, which functions to reduce inflammation [53], potentially counteracting the expression of genes related to the inflammatory response in the intestine. Other genes involved in the innate immune response were expressed at lower level in fish fed PP. IL-8 is a chemokine that attracts neutrophils to a site of inflammation [54], whereas IL-17D coordinates the clearance of extracellular bacteria and contributes to the pathology of many autoimmune and allergic conditions in Atlantic salmon [55]. The lower expression of these genes in fish fed the PP diet may indicate there was not a proinflammatory response to the PP diet compared to MP diet.

Several antioxidant genes were expressed higher in PP fed fish mid intestine indicating protection against oxidative damage. The free radicals could be either endogenously produced by immune cells or present in the diet. Alternatively a potential lower concentration of antioxidants in the PP feed, due to the lower fishmeal content, may require the antioxidant system within the fish to be increased accordingly. The overall low expression of heat shock protein mRNAs, suggests a limited stress response in the intestine. Additionally, two genes directly involved in apoptosis process (caspase-3 and14) were expressed at higher level in PP potentially indicating increased apoptotic activity of mid intestinal cells in these fish compared to MP fed fish.

The intestine has an extremely high rate of cellular turnover and hence generally high levels of protein synthesis and protein degradation. Protein metabolism genes relating to both synthesis and degradation were found generally to be higher in PP fed fish suggesting an increase in intestinal protein turnover. Genes related to both transcription and translations were at a higher level such as translation initiation factors, elongation factors and the ribosomal protein S6 kinase. Interestingly, a number of mRNAs encoding ribosomal proteins were at a lower expression in PP. This may relate to the stability of the mRNAs or multiple use of the ribosomal subunits during translation. In parallel to general increase in synthesis genes related to protein degradation were also at a higher level in PP such as cathepsins and components of the ubiqutin proteasome pathway [56,57]. The higher protein turnover is likely to be energy demanding and this is related to an increase in genes encoding proteins involved in oxidative energy metabolism. Together these changes in expression suggest modulation in control of protein turnover in the intestine with components of both synthesis and degradation being altered which may reflect an increased activity of the intestine in fish fed the PP compared to the MP diet.

Cellular membrane transport related genes were higher expressed in PP, which could suggest that salmonids are able to adaptively modulate the densities of transporters to match changes in diet composition. Lipid metabolism and transport were also affected even though the PP diet contained the same fish oil content as the MP diet. mRNAs encoding two apolipoproteins were higher in expression in PP fed fish reflecting a greater mobilization and transport of cholesterol and fatty acids in the intestine, possibly an adaptive response to the lower dietary cholesterol content in PP compared to MP diet. Fatty acid metabolism genes were higher expressed in the PP diet including both FAD5 and 6, a PUFA elongase and other genes related to cholesterol metabolism. FADs are critical enzymes in the biosynthesis of long-chain highly unsaturated fatty acids (HUFA) from shorter chain PUFA [58,59]. These lipid metabolism differences between PP and MP are of interest as the intestine is often over looked regarding these processes and cholesterol, even if the essential fatty acids are present at required levels, other factors including cholesterol may change, revealing the complex 
nature of the early digestion and modifications of nutrients in the mid intestine.

\section{Transcriptome changes in the liver}

The liver receives nutrients and compounds from the intestine and needs to respond to any substances that may have detrimental effects on the fish.

Transcriptome and proteomic studies on salmonids show nutritionally related modifications in both liver mRNAs and proteins due to feeding status $[60,61]$ and diet composition [9,62-64].

The PP fed fish showed a significant difference to fish fed MP for genes related to immune function with a lower expression of innate factors such as lectins and hepcidin. Acquired immune system components were also found at lower level including $\mathrm{T}$ cell receptors, MHC I and II and components of the TGF- $\beta$ pathway. TGF- $\beta$ has an important role in the maintenance of T-cell [65] and B-cell homeostasis [66] by regulating cell proliferation process and apoptosis in these cells. This result, with the higher expression of genes involved in cell death such as CIDE-3 and angiopoietin-related protein 4, indicates that apoptosis may be a mechanism induced by the PP diet salmon liver. This is not surprising as apoptosis plays a central role in the differentiation and maintenance of the liver [67]. A balancing effect on the apoptotic TGF- $\beta$ pathway is seen in the induction of several genes encoding proteins related to cell proliferation (such as HTRA1 serine protease and annexin A3). In particular, HTRA1 serine protease inhibits signalling mediated by TGF- $\beta$ family proteins [68], playing an important role in contrast to cell death, whereas annexin A3 has a role in the signalling cascade during liver regeneration [69]. Other researchers have found the immune system to be altered following vegetable oil replacement in salmon [28] and in sea bass [70].

Genes involved in oxidative stress response (MPV17 protein, amine oxidase and HSP $70 \mathrm{kDa}$ protein) were higher in liver of fish fed PP compared to MP. This is interesting to note as increases in antioxidant genes were also noted in a salmon diets that had marine oil replaced with vegetable oils [28] in the liver. In rainbow trout HSP expression in liver was increased following SBM rich replacement diets $[9,62,63,71]$, the induction of these genes may indicate a diet-induced stress response in fish fed the PP diet. Moreover, during general high protein turnover to deal with misfolded proteins [72] as may be the case of fish fed PP diet.

It is interesting to note that few lipid related metabolic genes were found significantly different in the liver. Vigilin, a protein implicated in both biosynthesis and metabolism of lipids and steroids, facilitates removal of excess cholesterol from cells [73] and secondly apolipoprotein A IV which facilitates transport of cholesterol to the liver were both expressed at higher level in fish fed PP compared to MP. The high expression of apolipoproteins in fish fed diets containing high levels of plant proteins has previously been observed $[9,74]$ and is most likely indicates reduced cellular cholesterol in fish fed the PP diet due to decreased dietary cholesterol, associated with low fishmeal content, and/or in response to trace levels of phytoestrogens [75] and phorbol esters [76] co purified with the plant proteins.

\section{Transcriptome changes in the skeletal muscle}

Genes related to processes such as protein metabolism, energy metabolism, cell proliferation, apoptosis and immune function were all significantly different in PP fed fish compared to MP. Transcripts related to protein metabolism such as ribosomal protein mRNAs, transcription and translation initiation factors were generally lower in PP fed fish compared to MP fed fish indicating lower protein synthesis. In parallel, protein degradation related genes were also less, for example the ubiquitin proteasome pathway and lysosomal peptidase proteins, together these would suggest a lower protein turnover activity in the muscle tissue in PP group. Both protein synthesis and degradation are highly energy demanding processes [77] and the indication of lower protein turnover, may suggest reduced energy wastage $[61,78,79]$. This idea is strengthened by lower expression of COX2 and COX8 and other genes encoding proteins involved in glycolysis and gluconeogenesis in fish fed PP. Genes involved in cell proliferation were also expressed at lower levels in PP fed fish indicating further energy saving. Together these changes in biological processes may indicate efficient metabolic activity following feeding of the plant protein enriched diet.

Biological tissues with high metabolic rate require mechanisms to deal with free oxygen radicals, on the other hand those tissues where the metabolic rate is reduced, for example when protein turnover is decreased a reduction in oxidative stress response may be observed as was observed in this study. Additionally a number of HSPs 30, 47 and a heat shock transcription factor 1a were all at lower levels in PP reflecting the reduced protein turnover and requirement of stabilising many newly translated proteins. Genes involved in cell proliferation and related to cell death including two caspases (caspase- 8 and 14) were also lower expressed in fish fed PP compared to the MP diet. The induction of bh3 interacting domain death agonist, a pro-apoptotic member of the $\mathrm{Bcl}-2$ protein family [80] and the suppression of caspases is in accordance with apoptosis of skeletal muscle in mammals where the $\mathrm{Bcl} 2 /$ bax system was found crucial for muscle apoptosis, whilst the caspase activity appeared inhibited [81]. 
Differential expression of a number of immune related genes, particularly a decrease in interferon responsive genes including $\gamma$-ip [82], Gig2-like [83] and interferoninduced protein 35 [84] were also expressed at lower level in PP. Other pro-inflammatory agents including platelet-activating factor receptor was also at a lower level PP, which regulates several pro-inflammatory functions such as chemokine and eicosanoid receptors [85]. An antimicrobial peptide beta defensin 1 which is a central component of the non-specific defences [86] was also found lower in PP. Relating to the adaptive immune factors, TCR $\beta$, MHCI and CD80 were all at lower levels in PP. Although we have observed differences in genes related to immune function in skeletal muscle of fish fed PP, the low level of inflammation and the subsequent immune response observed in the intestine did not cause a large immune shift in the muscle tissue. Instead, the lower expression of such genes, may allow fish fed PP to spend less energy resources on immune function for use in growth [61].

\section{Conclusions}

In conclusion, the present study confirm that a moderate level of plant protein derived proteins in a salmon diet allowed fish to grow with equal efficiency as those on a high marine protein diet, and with no difference in biometric quality parameters. The PP diet formulated with higher levels of soy protein concentrate, corn gluten, sunflower meal and wheat gluten resulted in significant effects on transcription in the mid intestine, liver, and skeletal muscle. The PP diet induced tissue specific changes in gene expression, with the mid intestine showing activation of the adaptive immune response indicating potential for hypersensitivity and an increase in protein turnover, although no difference in histopathological changes were observed in the proximate, mid or distal intestine. In liver cell proliferation and apoptosis indicate cellular reorganization and the general suppression of processes such as immune response. In contrast skeletal muscle tissue showed reduced protein metabolism and decrease in immune gene expression suggesting less energy expenditure in this tissue. The presence of only few genes in common between tissues may be due to the relatively mild changes that occurred and the complex nature of studying gene expression between tissue types on conservative dietary changes. These results improve the understanding of mechanisms and pathways activated by fishmeal replacement; in particular substitution by plant derived proteins and suggests that such diets can function well in Atlantic salmon aquaculture, hence to some extent reducing the burden on wild caught fish for fish meal. Additionally these results can assist in selection of molecular biomarkers useful for the development of new alternative feeds in salmonid aquaculture.

\section{Methods}

\section{Fish husbandry and sampling}

One hundred and five juvenile mixed sex Atlantic salmon of approximately $100 \mathrm{~g}$ were maintained in 6 replicate $1 \mathrm{~m}^{3}$ tanks at SGS Chile Ltd., Puerto Mont, Chile, at $10.1^{\circ} \mathrm{C}$ and $27.6 \%$ salinity. Fish were fed a plant protein diet (PP) or a high marine protein diet (MP), both of which were formulated to the same digestible protein and energy content within formulation constraints of a commercial feed specification (CPK 100, $3 \mathrm{~mm}, 24 / 44$ lipid: protein, BioMar S.A., Chile) (Table 1). The feeding trial was conducted in triplicate tanks per dietary treatment and lasted for 77 days. At the end of the feeding period all fish in each tank were bulk weighed and 35 fish from each tank were killed by percussive stunning for individual biometric measurements of round weight, fork length, gutted weight, and weight of liver, heart or intestine for calculation of specific growth rate (SGR), feed conversion ratio (FCR), specific feeding rate (SFR), condition factor, and somatic indices of hepatic (HSI), cardiac (CSI) or intestinal (ISI) organs. Liver, heart and intestine was excised from distinct anatomical regions of the same individuals and fixed in 10\% buffered formalin for histological assessment. All fish were sampled 30 minutes following the final meal to ensure there were no differences in postprandial gene expression. An additional 12 fish from each tank were sampled for mid intestine, skeletal muscle and liver and immediately stabilised in RNAlater (Ambion) at $4^{\circ} \mathrm{C}$ overnight then stored at $-20^{\circ} \mathrm{C}$ until RNA extraction for gene expression analysis.

\section{Growth/feed parameters were calculated as follows}

$\mathrm{FCR}=$ feed consumed $(\mathrm{g}) /$ biomass increase $(\mathrm{g})$

SGR $\left(\%\right.$ body wt d $\left.{ }^{-1}\right)=\left[\left(\ln W_{2}-\ln W_{1}\right) /\right.$ days $] \times 100$;

$W_{1}=$ start weight $(\mathrm{g}), W_{2}=$ final weight $(\mathrm{g})$, days = days in the growth period

SFR $(\%)=$ SGR $\times$ FCR

HSI, CSI, ISI $(\%)=[$ organ weight $(\mathrm{g}) /$ round weight (g) $] \times 100$

Condition factor $=[$ round weight $(g) \times 100] /[$ fork length $(\mathrm{cm})]^{3}$

Biometric parameters were analyzed for significant differences by Anova using InfoStat v 2009 software (University of Córdoba, Argentina), with $\mathrm{p}<0.05$ considered significant. Data is presented as means \pm standard deviation for each dietary treatment.

\section{Histology assessment}

Fixed tissues were submitted to dehydration process following paraffin embedding (Aquagestión, Puerto Montt, 
Chile). Sections $(5 \mu \mathrm{m})$ were stained with hematoxylin and eosin (H \& E) and examined under a light microscope. Micrographs were examined "blind" by the same experienced pathologist. Liver sections were evaluated for lipid degeneration level (fatty change) and the integrity of the whole organ. Heart tissue was evaluated for the presence of inflammatory infiltrates, myodegeneration and other possible abnormalities. Intestinal morphology was evaluated according to the following criteria: a) widening and shortening of intestinal folds, 2) loss of supranuclear vacuolization in enterocytes in the intestinal epithelium, 3) widening of central lamina propria within the intestinal folds, and 4) infiltration of (mixed) leukocytes in the lamina propria and submucosa [33]. The occurrence of histological changes for each dietary treatment were analysed by Kruskal-Wallis non-parametric Anova with InfoStat v 2009 (University of Córdoba, Argentina), with $\mathrm{p}<0.05$ considered significant.

\section{RNA isolation}

RNA was extracted from $100 \mathrm{mg}$ of tissue by homogenisation in $1 \mathrm{ml}$ TRIZol (Invitrogen) using tungsten carbide beads (3 mm, Qiagen) and shaking (300 times per min) following the manufacturer's instructions. The RNA pellet was washed in $500 \mu \mathrm{l} 80 \%$ ethanol, air dried and resuspended in $\mathrm{RNase}$ free $\mathrm{H}_{2} \mathrm{O}$. The concentration was determined by spectrophotometry (Nanodrop ND1000, LabTech) and the integrity of the RNA was determined by electrophoresis (Agilent Bioanalyser 2100). The RNA was then stored at $-80^{\circ}$ until required.

\section{Microarray analysis}

Microarray platform:

Microarray experiments were performed using a custom-designed, Agilent-based microarray platform with $4 \times 44 \mathrm{~K}$ probes per slide (Salar_2; Agilent Design ID:025520). The array contained primarily an Atlantic salmon resource with 34,441 features from Atlantic salmon coding sequences but additionally a further 9,111 features from rainbow trout (Oncorhynchus mykiss) sequences - the latter being selected when no homologues appeared to be available within Salmo salar datasets. Full details of the microarray platform and design are shown in Tacchi et al. 2011 [23].

\section{Hybridization and analysis}

For microarray analysis, 4 pools of RNA were produced for each tissue from fish fed PP and MP diets. Each RNA pool was an equimolar RNA mix from four different fish chosen randomly from each group. The microarray hybridisation was performed using a reference design, using a reference RNA sample, which comprised an equimolar mix of RNA extracted from all individual fish and tissue samples. Each experimental sample (labelled with $\mathrm{Cy} 3^{\mathrm{TM}}$ ) was hybridised against this reference sample (labelled with $\mathrm{Cy} 5^{\mathrm{TM}}$ ) in a 2-colour experiment. mRNA amplification, labelling and hybridization was performed as follows: mRNA was amplified using a MessageAMP ${ }^{\mathrm{TM}}$ aRNA Amplification Kit (Ambion). Briefly, $2 \mu \mathrm{g}$ total RNA was reverse transcribed and the cDNA was used as a template for in vitro transcription in the presence of amino allyl modified dUTP, which allowed the generation of amplified antisense RNA (aRNA). For labelling, aRNA (3 $\mu \mathrm{g}$ ) was denatured at $70^{\circ} \mathrm{C}$ for $2 \mathrm{~min}$ in a volume of $10 \mu \mathrm{l}$ to which $3 \mu \mathrm{l}$ of $0.5 \mathrm{M} \mathrm{NaHCO}_{3}$ and $2 \mu \mathrm{l} \mathrm{Cy}$ dye (dye $\mathrm{Cy}^{\mathrm{TM}}$ or $\mathrm{Cy}^{\mathrm{TM}}$ mono-reactive dye pack, Amersham) was added. Incorporation of dyes was performed for $1 \mathrm{~h}$ in the dark, and after excess label was removed using a DyeEx ${ }^{\mathrm{TM}} 2.0$ spin kit (QIAGEN) the amount incorporated was checked with a Nanodrop ND1000 (LabTech) spectrophotometer. Prior to hybridisation, $825 \mathrm{ng}$ of each labelled template was fragmented in the presence of $11 \mu \mathrm{l}$ of $10 \mathrm{X}$ blocking agent, $2.2 \mu \mathrm{l}$ of 25X Fragmentation buffer (Agilent), and made up to a final volume of $20 \mu \mathrm{l}$ with nuclease-free $\mathrm{dH}_{2} \mathrm{O}$. The solution was then incubated in the dark at $60^{\circ} \mathrm{C}$ for $30 \mathrm{~min}$, after which $57 \mu \mathrm{l}$ of $2 \mathrm{X}$ GEx Hybridisation buffer (Agilent) was added to each sample and $103 \mu \mathrm{l}$ of each hybridisation solution was dispensed on the Agilent 4x44K Atlantic salmon "Salmo salar2" oligo array (Agilent array design, 025520, Array express platform A-MEXP1940). The hybridisations were performed in a Microarray Hybridisation Oven (Agilent) overnight $(18 \mathrm{~h})$ at $65^{\circ} \mathrm{C}$. Following hybridisation, the slides were washed in Gene Expression Wash buffers 1 and 2 (Agilent) following the manufacturer's instructions. The slides were then scanned using a GenePix personal 4100A Scanner (Axon Instruments) at a resolution of $5 \mu \mathrm{m}$ and saved as *. TIF files. Images were extracted and initial analysis was performed by Feature extraction v9.5.3 (Agilent) performing background correction of feature intensities (within the software). A Lowess normalisation of background corrected data was next conducted and all intensity values $<1.0$ were set to 1.0. Statistical analysis of the arrays was performed using Genespring GX analysis platform (version 9.5; Agilent Technologies). Quality control of the data was performed within Genespring and included removal of saturated probe features, non-uniform features, population outliers and those features showing intensities not significantly different from background in the Cy3 or Cy5 channels. After these relatively stringent procedures, 20,095 of the original 43,730 array features were maintained for subsequent analyses. The experimental hybridisations are at European Bioinformatics Institute archived under accession number E-MEXP: E-TABM-1207.

Significant differential expression between fish fed the PP diet and fish fed the control diet was established by $t$-test analysis $(p<0.05)$. Further filtering on fold change was conducted, and only transcripts showing more 
than two-fold change in expression were further characterised.

\section{Analysis of gene ontology}

Enrichment for gene ontology (GO) biological processes was performed on all cDNA features that had GO identifiers associated using the GOEAST program [87]. Fisher's exact test was performed within the GOEAST program to determine if $\mathrm{GO}$ identifiers occurred more often in a group than would appear by chance. For GO analysis only biological process $\mathrm{GO}$ identifiers were considered that occurred more than 3 times.

\section{Real time PCR}

The cDNA was synthesized using $2 \mu \mathrm{g}$ of total RNA as previously described [88]. Real time PCR was performed on a number of genes to confirm the microarray analysis results using the same RNA samples. For cDNA synthesis, $2 \mu \mathrm{g}$ of total RNA was denatured $\left(70^{\circ} \mathrm{C}, 3 \mathrm{~min}\right)$ in the presence of $1 \mu \mathrm{l}$ of oligo- $\mathrm{dT}_{17}\left(500 \mathrm{ng} \mathrm{\mu l}^{-1}\right)$, left at room temperature for $5 \mathrm{~min}$ to allow annealing, then stored on ice. The resulting cDNA was diluted to a final volume of $50 \mu \mathrm{l}$ in RNA/DNA free water (Sigma). For real time PCR, $3 \mu \mathrm{l}$ of $\mathrm{cDNA}$ was used as template with gene specific primers (Table 7). A 2x iQ SYBR Green supermix (Bio-Rad) was used for qPCR, which was performed in a 96-well plate using the DNA Engine OpticonTM system (MJ Research, Inc.) with the following program: $95^{\circ} \mathrm{C}$ for $5 \mathrm{~min}$, then 35 cycles of $94^{\circ} \mathrm{C}$ for $30^{\circ} \mathrm{s}$, $55^{\circ} \mathrm{C}$ for $30 \mathrm{~s}$ and $72^{\circ} \mathrm{C}$ for $30 \mathrm{~s}$, with a final extension of $72^{\circ} \mathrm{C}$ for $5 \mathrm{~min}$. A negative control (no template) reaction was also performed for each primer pair. A sample from the serial dilution was run on a $2 \%$ agarose gel and stained with ethidium bromide and viewed under UV light to confirm a band of the correct size was amplified. A melting curve for each PCR was determined by reading fluorescence every degree between $72^{\circ} \mathrm{C}$ and $95^{\circ} \mathrm{C}$ to ensure only a single product had been amplified. Atlantic salmon hypoxanthine phosphoribosyl transferase 1 (HPRT1) [89] was used as control for normalization of expression since this gene was found not to be modulated by the diet treatments from the microarray analysis. The relative expression level of the genes was determined using the Pfaffl method [90]. Efficiency of the amplification was determined for each primer pair using serial 10 fold dilutions of pooled cDNA, performed on the same plate as the experimental samples. The efficiency was calculated as $\mathrm{E}=10^{(-1 / \mathrm{s})}$ where $\mathrm{s}$ is the slope generated from the serial dilutions, when Log dilution is plotted against $\Delta \mathrm{CT}$ (threshold cycle number). Primers were design to have a $\mathrm{Tm}$ of $55^{\circ} \mathrm{C}$, and where possible, to cross an exon-exon junction sites to avoid amplification of genomic DNA. Exon-intorn junction sites were determined comparing Salmo salar cDNA with genomic sequences for orthologous genes from Danio rerio, Gasterosteus aculeatus, Oryzias latipes, Takifugu rubripes and Tetraodon nigroviridis obtained from Ensembl (http://ensembl.org/).

The results obtained by real time PCR were analyzed using the Pfaffl method [90]. The qPCR measurements were analyzed by $T$-test, performed using $\mathrm{R}$ software, with $\mathrm{p}<0.05$ considered significant. The expression data is presented as means \pm standard error.

\section{Competing interests}

The authors declare that they have no competing interests.

\section{Author's contributions}

LT performed microarray experiments, analyzed the data, carried out the real time PCR and wrote the manuscript. MAC, CV and HT were involved in fish maintenance, feeding trial and sampling. SAMM, CJS, RB and MAC were involved in the experimental design and drafting of the manuscript. All the authors read and approved the final manuscript.

\section{Acknowledgements}

The research was supported by an industrial studentship between the University of Aberdeen and BioMar Ltd (for L. Tacchi). The authors are grateful to AVS Chile S.A. and the staff at SGS Chile for conducting the feeding experiment and assistance during sampling.

\section{Author details}

${ }^{1}$ Institute of Biological and Environmental Sciences, University of Aberdeen, Tillydrone Avenue, Aberdeen AB24 2TZ, UK. ${ }^{2}$ BioMar Ltd, Grangemouth Docks, Grangemouth FK3 8UL, UK. ${ }^{3}$ AVS Chile S.A., Casilla 300, Puerto Varas, Chile. ${ }^{4}$ Nofima, P.O. Box 5010, 1432, Aas, Norway.

Received: 22 November 2011 Accepted: 19 July 2012

Published: 1 August 2012

\section{References}

1. Tacon AGJ: Aquaculture: A catch for all? OECD Obs 2010, 278:32.

2. Tacon AGJ: FAO Fisheries Circular (FAO), no. 881 / FAO. In Feed ingredients for carnivorous fish species: alternatives to fishmeal and other fishery resources. Rome (Italy): Fishery Resources and Environment Div; 1994:39.

3. F.A.O: State of the World Fisheries and Aquaculture. Rome: FAO; 2007.

4. ICES: Report of the Working Group on North Atlantic Salmon (WGNAS), 13 April 2006,ICES Headquarters. ICES Headquarters 2006: ICES CM 2006/ACFM. 2023.

5. ICES: Report of the Working Group on North Atlantic Salmon (WGNAS),30 March-8 April 2009,Copenahagen, Denmark. ICES CM 2009/ACOM:06; 2009.

6. F.A.O: Review of the state of world marine fishery resources. In FAO fisheries technical paper, 457. Rome: FAO; 2005:235.

7. Gatlin DM, Barrows FT, Brown P, Dabrowski K, Gaylord TG, Hardy RW, Herman E, Hu G, Krogdahl A, Nelson R, et al: Expanding the utilization of sustainable plant products in aquafeeds: A review. Aquac Res 2007 38(6):551-579.

8. Krogdahl $\AA$, Penn M, Thorsen J, Refstie S, Bakke AM: Important antinutrients in plant feedstuffs for aquaculture: An update on recent findings regarding responses in salmonids. Aquac Res 2010, 41(3):333-344

9. Martin SAM, Vilhelmsson O, Médale F, Watt P, Kaushik S, Houlihan DF: Proteomic sensitivity to dietary manipulations in rainbow trout. Biochim Biophys Acta Proteins Proteomics 2003, 1651(1-2):17-29.

10. Bakke-McKellep AM, Frøystad MK, Lilleeng E, Dapra F, Refstie S, Krogdahl A Landsverk T: Response to soy: T-cell-like reactivity in the intestine of Atlantic salmon, Salmo salar L. J Fish Dis 2007, 30(1):13-25.

11. Urán PA, Aydin R, Schrama JW, Verreth JAJ, Rombout JHWM: Soybean meal-induced uptake block in Atlantic salmon Salmo salar distal enterocytes. J Fish Biol 2008, 73(10):2571-2579.

12. Gómez-Requeni P, Mingarro M, Kirchner S, Calduch-Giner JA, Médale F, Corraze G, Panserat S, Martin SAM, Houlihan DF, Kaushik SJ, et al: Effects of 
dietary amino acid profile on growth performance, key metabolic enzymes and somatotropic axis responsiveness of gilthead sea bream (Sparus aurata). Aquaculture 2003, 220(1-4):749-767.

13. Francis G, Makkar HPS, Becker K: Antinutritional factors present in plantderived alternate fish feed ingredients and their effects in fish. Aquaculture 2001, 199(3-4):197-227.

14. Zhao $H$, Jiang $R$, Xue $M$, Xie S, Wu X, Guo L: Fishmeal can be completely replaced by soy protein concentrate by increasing feeding frequency in Nile tilapia (Oreochromis niloticus GIFT strain) less than $2 \mathrm{~g}$. Aquac Nutr 2010, 16(6):648-653.

15. Escaffre AM, Kaushik S, Mambrini M: Morphometric evaluation of changes in the digestive tract of rainbow trout (Oncorhynchus mykiss) due to fish meal replacement with soy protein concentrate. Aquaculture 2007, 273(1):127-138.

16. Kaushik SJ, Cravedi JP, Lalles JP, Sumpter J, Fauconneau B, Laroche M: Partial or total replacement of fish meal by soybean protein on growth, protein utilization, potential estrogenic or antigenic effects, cholesterolemia and flesh quality in rainbow trout, Oncorhynchus mykiss. Aquaculture 1995, 133(3-4):257-274.

17. Gaylord TG, Teague AM, Barrows FT: Taurine supplementation of all-plant protein diets for rainbow trout (Oncorhynchus mykiss). J World Aquaculture Soc 2006, 37(4):509-517.

18. Gill N, Higgs DA, Skura BJ, Rowshandeli M, Dosanjh BS, Mann J, Gannam AL: Nutritive value of partially dehulled and extruded sunflower meal for post-smolt Atlantic salmon (Salmo salar L.) in sea water. Aquac Res 2006, 37(13):1348-1359.

19. Mente E, Deguara S, Begoña Santos M, Houlihan D: White muscle free amino acid concentrations following feeding a maize gluten dietary protein in Atlantic salmon (Salmo salar L.). Aquaculture 2003, 225(1-4):133-147.

20. Thiessen DL, Campbell GL, Adelizi PD: Digestibility and growth performance of juvenile rainbow trout (Oncorhynchus mykiss) fed with pea and canola products. Aquac Nutr 2003, 9(2):67-75

21. Espe $M$, Lemme A, Petri A, El-Mowafi A: Assessment of lysine requirement for maximal protein accretion in Atlantic salmon using plant protein diets. Aquaculture 2007, 263(1-4):168-178.

22. Penn MH, Bendiksen EA, Campbell P, Krogdahl AS: High level of dietary pea protein concentrate induces enteropathy in Atlantic salmon (Salmo salar L.). Aquaculture 2011, 310(3-4):267-273.

23. Tacchi L, Bron JE, Taggart JB, Secombes CJ, Bickerdike R, Adler MA, Takle H, Martin SAM: Multiple tissue transcriptomic responses to Piscirickettsia salmonis in Atlantic salmon (Salmo salar). Physiol Genom 2011, 43(21):1241-1254.

24. Panserat S, Hortopan GA, Plagnes-Juan E, Kolditz C, Lansard M, Skiba-Cassy S, Esquerré D, Geurden I, Médale F, Kaushik S, et al: Differential gene expression after total replacement of dietary fish meal and fish oil by plant products in rainbow trout (Oncorhynchus mykiss) liver. Aquaculture 2009, 294(1-2):123-131.

25. Le Boucher R, Quillet E, Vandeputte M, Lecalvez JM, Goardon L, Chatain B, Médale F, Dupont-Nivet M: Plant-based diet in rainbow trout (Oncorhynchus mykiss): Are there genotype-diet interactions for main production traits when fish are fed marine vs. plant-based diets from the first meal? Aquaculture 2011, 321(1-2):41-48.

26. Pierce LR, Palti $Y$, Silverstein JT, Barrows FT, Hallerman EM, Parsons JE: Family growth response to fishmeal and plant-based diets shows genotype $\mathrm{x}$ diet interaction in rainbow trout (Oncorhynchus mykiss). Aquaculture 2008, 278(1-4):37-42.

27. Kolditz Cl, Plagnes-Juan E, Quillet E, Lefèvre F, Médale F: Changes in white muscle transcriptome induced by dietary energy levels in two lines of rainbow trout (Oncorhynchus mykiss) selected for muscle fat content. $\mathrm{Br} J$ Nutr 2010, 103(5):629-642.

28. Morais S, Pratoomyot J, Taggart J, Bron J, Guy D, Bell JG, Tocher D: Genotype-specific responses in Atlantic salmon (Salmo salar) subject to dietary fish oil replacement by vegetable oil: a liver transcriptomic analysis. BMC Genom 2011, 12(1):255.

29. Tacon AGJ, Metian M: Global overview on the use of fish meal and fish oil in industrially compounded aquafeeds: Trends and future prospects. Aquaculture 2008, 285(1-4):146-158.

30. Morais S, Pratoomyot J, Taggart J, Bron J, Guy D, Bell J, Tocher D: Genotype-specific responses in Atlantic salmon (Salmo salar) subject to dietary fish oil replacement by vegetable oil: a liver transcriptomic analysis. BMC Genom 2011, 12(1):255.
31. Jafri M, Donnelly B, Bondoc A, Allen S, Tiao G: Cholangiocyte secretion of chemokines in experimental biliary atresia. J Pediatr Surg 2009, 44(3):500-507

32. Mack CL, Tucker RM, Sokol RJ, Kotzin BL: Armed CD4+ Th1 effector cells and activated macrophages participate in bile duct injury in murine biliary atresia. Clin Immunol 2005, 115(2):200-209.

33. Baeverfjord G, Krogdahl Å: Development and regression of soybean meal induced enteritis in Atlantic salmon, Salmo salar L., distal intestine: A comparison with the intestines of fasted fish. J Fish Dis 1996, 19(5):375-387.

34. van den Ingh TSGAM, Krogdahl $\AA$, Olli JJ, Hendriks HGCJM, Koninkx JGJF: Effects of soybean-containing diets on the proximal and distal intestine in Atlantic salmon (Salmo salar): a morphological study. Aquaculture 1991, 94(4):297-305.

35. Sanden M, Berntssen MHG, Krogdahl A, Hemre Gl, Bakke-McKellep AM: An examination of the intestinal tract of Atlantic salmon, Salmo salar L., parr fed different varieties of soy and maize. J Fish Dis 2005, 28(6):317-330.

36. Salinas I, Meseguer J, Esteban MÁ: Assessment of different protocols for the isolation and purification of gut associated lymphoid cells from the gilthead seabream (Sparus aurata L.). Biol Proced Online 2007, 9(1):43-55.

37. Collie NL, Ferraris RP: Chapter 9 Nutrient fluxes and regulation in fish intestine. Biochemistry and Molecular Biology of Fishes 1995, 4:221-239.

38. Bakke-McKellep AM, Nordrum S, Krogdahl $\AA$, Buddington RK: Absorption of glucose, amino acids, and dipeptides by the intestines of Atlantic salmon (Salmo salar L.). Fish Physiol Biochem 2000, 22(1):33-44.

39. Bureau DP, Harris AM, Young Cho C: The effects of purified alcohol extracts from soy products on feed intake and growth of chinook salmon (Oncorhynchus tshawytscha) and rainbow trout (Oncorhynchus mykiss). Aquaculture 1998, 161(1-4):27-43.

40. Rumsey GL, Siwicki AK, Anderson DP, Bowser PR: Effect of soybean protein on serological response, non-specific defense mechanisms, growth, and protein utilization in rainbow trout. Vet Immunol Immunopathol 1994, 41(3-4):323-339.

41. Krogdahl A, Bakke-McKellep AM, Baeverfjord G: Effects of graded levels of standard soybean meal on intestinal structure, mucosal enzyme activities, and pancreatic response in Atlantic salmon (Salmo solar L.). Aquac Nutr 2003, 9(6):361-371.

42. Bernard D, Six A, Rigottier-Gois L, Messiaen S, Chilmonczyk S, Quillet E, Boudinot $P$, Benmansour A: Phenotypic and functional similarity of gut intraepithelial and systemic T cells in a teleost fish. J Immunol 2006, 176(7):3942-3949.

43. Riccardi C, Cifone MG, Migliorati G: Glucocorticoid hormone-induced modulation of gene expression and regulation of T-cell death: Role of GITR and GILZ, two dexamethasone-induced genes. Cell Death Differentiation 1999, 6(12):1182-1189.

44. Delfino DV, Agostini M, Spinicelli S, Vacca C, Riccardi C: Inhibited cell death, NF-KB activity and increased IL-10 in TCR-triggered thymocytes of transgenic mice overexpressing the glucocorticoid-induced protein GILZ. Int Immunopharmacol 2006, 6(7):1126-1134.

45. Wilson S, Blaschek K, Gonzalez De Mejia E: Allergenic proteins in soybean: Processing and reduction of P34 allergenicity. Nutr Rev 2005, 63(2):47-58.

46. Jacobs MD, Harrison SC: Structure of an IKBa/NF-kB complex. Cell 1998 95(6):749-758

47. Takeda K, Kaisho T, Akira S: Toll-like receptors. Annu Rev Immunol 2003, 21:335-376.

48. Honda K, Yanai H, Negishi H, Asagiri M, Sato M, Mizutani T, Shimada N, Ohba Y, Takaoka A, Yoshida N, et al: IRF-7 is the master regulator of type-I interferon-dependent immune responses. Nature 2005, 434(7034):772-777.

49. Sun B, Skjaeveland I, Svingerud T, Zou J, Jorgensen J, Robertsen B: Antiviral Activity of Salmonid Gamma Interferon against Infectious Pancreatic Necrosis Virus and Salmonid Alphavirus and Its Dependency on Type I Interferon. J Virol 2011, 85(17):9188-9198.

50. Robertsen B, Trobridge G, Leongt J-A: Molecular cloning of doublestranded RNA inducible MX genes from atlantic salmon (Salmo salar I.). Dev Comp Immunol 1998, 21(5):397-412.

51. Boudinot $P$, Salhi S, Blanco M, Benmansour A: Viral haemorrhagic septicaemia virus induces vig -2 , a new interferon-responsive gene in rainbow trout. Fish Shellfish Immunol 2001, 11(5):383-397. 
52. van der Aa LM, Levraud JP, Yahmi M, Lauret E, Briolat V, Herbomel P, Benmansour A, Boudinot P: A large new subset of TRIM genes highly diversified by duplication and positive selection in teleost fish. BMC Biol 2009, 7:7.

53. Martens N, Uzan G, Wery M, Hooghe R, Hooghe-Peters EL, Gertler A: Suppressor of Cytokine Signaling 7 Inhibits Prolactin, Growth Hormone, and Leptin Signaling by Interacting with STAT5 or STAT3 and Attenuating Their Nuclear Translocation. J Bio/ Chem 2005, 280(14):13817-13823.

54. Jimenez N, Coll J, Salguero FJ, Tafalla C: Co-injection of interleukin 8 with the glycoprotein gene from viral haemorrhagic septicemia virus (VHSV) modulates the cytokine response in rainbow trout (Oncorhynchus mykiss). Vaccine 2006, 24(27-28):5615-5626.

55. Kumari J, Larsen AN, Bogwald J, Dalmo RA: Interleukin-17D in Atlantic salmon (Salmo salar): Molecular characterization, 3D modelling and promoter analysis. Fish Shellfish Immunol 2009, 27(5):647-659.

56. Godiksen H, Morzel M, Hyldig G, Jessen F: Contribution of cathepsins B, L and $D$ to muscle protein profiles correlated with texture in rainbow trout (Oncorhynchus mykiss). Food Chem 2009, 113(4):889-896.

57. Tacchi L, Bickerdike R, Secombes CJ, Martin SAM: Muscle-Specific RING Finger (MuRF) cDNAs in Atlantic Salmon (Salmo salar) and Their Role as Regulators of Muscle Protein Degradation. Mar Biotechnol 2012, 14(1):35-45.

58. Zheng X, Torstensen BE, Tocher DR, Dick JR, Henderson RJ, Bell JG Environmental and dietary influences on highly unsaturated fatty acid biosynthesis and expression of fatty acyl desaturase and elongase genes in liver of Atlantic salmon (Salmo salar). Biochim Biophys Acta Mol Cell Biol Lipids 2005, 1734(1):13-24.

59. Hastings N, Agaba MK, Tocher DR, Zheng X, Dickson CA, Dick JR, Teale AJ: Molecular cloning and functional characterization of fatty acyl desaturase and elongase cDNAs involved in the production of eicosapentaenoic and docosahexaenoic acids from a-linolenic acid in Atlantic salmon (Salmo salar). Mar Biotechnol 2004, 6(5):463-474.

60. Martin SAM, Cash P, Blaney S, Houlihan DF: Proteome analysis of rainbow trout (Oncorhynchus mykiss) liver proteins during short term starvation. Fish Physiol Biochem 2001, 24(3):259-270.

61. Tacchi L, Bickerdike R, Douglas A, Secombes CJ, Martin SAM: Transcriptomic responses to functional feeds in Atlantic salmon (Salmo salar). Fish Shellfish Immunol 2011, 31(5):704-715.

62. Vilhelmson OT, Martin SAM, Médale F, Kaushik SJ, Houlihan DF: Dietary plant-protein substitution affects hepatic metabolism in rainbow trout (Oncorhynchus mykiss). Br J Nutr 2004, 92(1):71-80.

63. Taggart JB, Bron JE, Martin SAM, Seear PJ, Høyheim B, Talbot R, Carmichael $S N$, Villeneuve LAN, Sweeney GE, Houlihan DF, et al: A description of the origins, design and performance of the TRAITS-SGP Atlantic salmon Salmo salar L. CDNA microarray. J Fish Biol 2008, 72(9):2071-2094.

64. Martin SAM, Douglas A, Houlihan D, Secombes C: Starvation alters the liver transcriptome of the innate immune response in Atlantic salmon (Salmo salar). BMC Genom 2010, 11(1):418.

65. Lucas PJ, Kim SJ, Melby SJ, Gress RE: Disruption of T cell homeostasis in mice expressing a T cell-specific dominant negative transforming growth factor $\beta$ II receptor. J Exp Med 2000, 191(7):1187-1196.

66. Cazac BB, Roes J: TGF- $\beta$ receptor controls $B$ cell responsiveness and induction of IgA in vivo. Immunity 2000, 13(4):443-451.

67. Schuster N, Krieglstein K: Mechanisms of TGF- $\beta$-mediated apoptosis. Cell Tissue Res 2002, 307(1):1-14.

68. Oka C, Tsujimoto R, Kajikawa M, Koshiba-Takeuchi K, Ina J, Yano M, Tsuchiya A, Ueta $Y$, Soma A, Kanda $H$, et al: HtrA1 serine protease inhibits signaling mediated by Tgf $\beta$ family proteins. Development 2004, 131(5):1041-1053.

69. Harashima M, Harada K, Ito Y, Hyuga M, Seki T, Ariga T, Yamaguchi T, Niimi S: Annexin A3 expression increases in hepatocytes and is regulated by hepatocyte growth factor in rat liver regeneration. J Biochem 2008, 143(4):537-545.

70. Geay F, Ferraresso S, Zambonino-Infante J, Bargelloni L, Quentel C, Vandeputte M, Kaushik S, Cahu C, Mazurais D: Effects of the total replacement of fish-based diet with plant-based diet on the hepatic transcriptome of two European sea bass (Dicentrarchus labrax) halfsibfamilies showing different growth rates with the plant-based diet. BMC Genom 2011, 12(1):522.

71. Sagstad A, Sanden M, Krogdahl Å, Bakke-Mckellep AM, FrØystad M, Hemre Gl: Organs development, gene expression and health of
Atlantic salmon (Salmo salar L.) fed genetically modified soybeans compared to the near-isogenic non-modified parental line. Aquac Nutr 2008, 14(6):556-572.

72. Freeman ML, Borrelli MJ, Meredith MJ, Lepock JR: On the path to the heat shock response: Destabilization and formation of partially folded protein intermediates, a consequence of protein thiol modification. Free Radic Biol Med 1999, 26(5-6):737-745.

73. McKnight GL, Reasoner J, Gilbert T, Sundquist KO, Hokland B, McKernan PA, Champagne J, Johnson CJ, Bailey MC, Holly R, et al: Cloning and expression of a cellular high density lipoprotein-binding protein that is up-regulated by cholesterol loading of cells. J Bio/ Chem 1992, 267(17):12131-12141.

74. Bouraoui L, SÁNchez-Gurmaches J, Cruz-Garcia L, GutiéRrez J, Benedito-Palos L, PÉRez-SÁNchez J, Navarro I: Effect of dietary fish meal and fish oil replacement on lipogenic and lipoprotein lipase activities and plasma insulin in gilthead sea bream (Sparus aurata). Aquac Nutr 2011, 17(1):54-63.

75. Lamon-Fava S: Genistein Activates Apolipoprotein A-I Gene Expression in the Human Hepatoma Cell Line Hep G2. J Nutr 2000, 130(10):2489-2492.

76. Vandenbrouck Y, Lambert G, Janvier B, Girlich D, Bereziat G, MangeneyAndreani M: Transcriptional regulation of apolipoprotein A-I expression in Hep G2 cells by phorbol ester. FEBS Lett 1995, 376(1-2):99-102.

77. Houlihan DF, Carter CG, McCarthy ID: Nitrogen Metabolism and Excretion. In Protein Turnover in Animals. Edited by Walsh PJ, Wright P. Boca Raton, United States of America: CRC Press; 1995:1-32.

78. Martin SAM, Blaney S, Bowman AS, Houlihan DF: Ubiquitin-proteasomedependent proteolysis in rainbow trout (Oncorhynchus mykiss): Effect of food deprivation. Pflugers Arch Eur J Physiol 2002, 445(2):257-266.

79. Dobly A, Martin SAM, Blaney SC, Houlihan DF: Protein growth rate in rainbow trout (Oncorhynchus mykiss) is negatively correlated to liver 20 S proteasome activity. Comp Biochem Physiol Mol Integr Physiol 2004, 137(1):75-85.

80. Wang K, Yin XM, Chao DT, Milliman CL, Korsmeyer SJ: BID: A novel BH3 domain-only death agonist. Genes Dev 1996, 10(22):2859-2869.

81. Sandri M, Rossini K, Podhorska-Okolow M, Carraro U: Role of Apoptosis in Muscle Disorders. Basic Appl Myol 1999, 9(6):301-310.

82. Laing KJ, Bols N, Secombes CJ: A CXC chemokine sequence isolated from the rainbow trout Oncorhynchus mykiss resembles the closely related interferon- $\gamma$-inducible chemokines CXCL9, CXCL10 and CXCL11. Eur Cytokine Netw 2002, 13(4):462-473.

83. Jiang J, Zhang Y-B, Li S, Yu F-F, Sun F, Gui J-F: Expression regulation and functional characterization of a novel interferon inducible gene Gig2 and its promoter. Mol Immunol 2009, 46(15):3131-3140.

84. Bange FC, Vogel U, Flohr T, Kiekenbeck M, Denecke B, Böttger EC: IFP 35 is an interferon-induced leucine zipper protein that undergoes interferonregulated cellular redistribution. J Biol Chem 1994, 269(2):1091-1098.

85. Honda ZI, Ishii S, ShimizU T: Platelet-activating factor receptor. J Biochem 2002, 131(6):773-779.

86. Casadei E, Wang T, Zou J, González Vecino JL, Wadsworth S, Secombes CJ: Characterization of three novel $\beta$-defensin antimicrobial peptides in rainbow trout (Oncorhynchus mykiss). Mol Immunol 2009, 46(16):3358-3366.

87. Zheng Q, Wang XJ: GOEAST: a web-based software toolkit for Gene Ontology enrichment analysis. Nucleic Acids Res 2008, 36:W358-W363. Web Server issue.

88. Tacchi L, Bickerdike R, Secombes CJ, Pooley NJ, Urquhart KL, Collet B, Martin SAM: Ubiquitin E3 ligase atrogin-1 (Fbox-32) in Atlantic salmon (Salmo salar): Sequence analysis, genomic structure and modulation of expression. Comp Biochem Physiol Biochem Mol Biol 2010, 157(4):364-373.

89. Bower NI, Johnston IA: Selection of reference genes for expression studies with fish myogenic cell cultures. BMC Mol Biol 2009, 10:80.

90. Pfaffl MW: A new mathematical model for relative quantification in real-time RT-PCR. Nucleic Acids Res 2001, 29(9):e45.

\section{doi:10.1186/1471-2164-13-363}

Cite this article as: Tacchi et al:: Transcriptomic and physiological responses to fishmeal substitution with plant proteins in formulated feed in farmed Atlantic salmon (Salmo salar). BMC Genomics 2012 13:363. 